Article

\title{
Impact of Different Biochars on Microbial Community Structure in the Rhizospheric Soil of Rice Grown in Albic Soil
}

\author{
Dawei Yin ${ }^{1, \dagger}{ }^{+}$Hongyu Li ${ }^{1, \dagger}{ }^{+}$Haize Wang ${ }^{1}$, Xiaohong Guo ${ }^{1}{ }^{\circledR}$, Zhihui Wang ${ }^{1}$, Yandong Lv ${ }^{1} \mathbb{D}$, Guohua Ding ${ }^{2}$, \\ Liang Jin ${ }^{3, *}$ and Yu Lan ${ }^{4, *}$
}

1 College of Agricultural Science, Heilongjiang Bayi Agricultural University, Daqing 163319, China; yindazhiyindawei@126.com (D.Y.); ndrice@163.com (H.L.); whzhlj@163.com (H.W.); guoxh1980@163.com (X.G.); byndwzh@163.com (Z.W.); Lvyd_1978@163.com (Y.L.)

2 College of Cultivation and Cultivation, Heilongiiang Academy of Agricultural Sciences, Harbin 150000, China; hucheng229@126.com

3 College of Plant Nutrition and Resources, Beijing Academy of Agriculture and Forestry Sciences, Beijing 100097, China

4 College of Agricultural Science, Shenyang Agricultural University, Shenyang 110161, China

* Correspondence: jinliang19762003@aliyun.com (L.J.); lanyu312228@syau.edu.cn (Y.L.); Tel.: +86-010-51503819 (L.J.); +86-024-88487106 (Y.L.); Fax: +86-024-88421024 (Y.L.)

+ These authors contributed equally to this work.

\section{check for} updates

Citation: Yin, D.; Li, H.; Wang, H.; Guo, X.; Wang, Z.; Lv, Y.; Ding, G.; Jin, L.; Lan, Y. Impact of Different Biochars on Microbial Community Structure in the Rhizospheric Soil of Rice Grown in Albic Soil. Molecules 2021, 26, 4783. https://doi.org/ $10.3390 /$ molecules 26164783

Academic Editors: Mingqiang Li, Jianxun Ding, Yunlu Dai and Hon Fai Chan

Received: 29 June 2021

Accepted: 4 August 2021

Published: 7 August 2021

Publisher's Note: MDPI stays neutral with regard to jurisdictional claims in published maps and institutional affiliations.

Copyright: (c) 2021 by the authors Licensee MDPI, Basel, Switzerland. This article is an open access article distributed under the terms and conditions of the Creative Commons Attribution (CC BY) license (https:/ / creativecommons.org/licenses/by/ $4.0 /)$.
Abstract: The purpose of this study was to clarify the effects of biochar on the diversity of bacteria and fungi in the rice root zone and to reveal the changes in soil microbial community structure in the root zone after biochar application to provide a scientific basis for the improvement of albic soil. Rice and corn stalk biochar were mixed with albic soil in a pot experiment. Soil samples were collected at the rice maturity stage, soil nutrients were determined, and genomic DNA was extracted. The library was established using polymerase chain reaction (PCR) amplification. The abundance, diversity index, and community structure of the soil bacterial 16SrRNA gene V3 + V4 region and the fungal internal transcribed spacer-1 (ITS1) region were analyzed using Illumina second-generation high-throughput sequencing technology on the MiSeq platform with related bioinformatics. The results revealed that the biochar increased the soil nutrient content of albic soil. The bacteria ACE indexes of treatments of rice straw biochar (SD) and corn straw biochar (SY) were increased by $3.10 \%$ and $2.06 \%$, respectively, and the fungi ACE and Chao indices of SD were increased by $7.86 \%$ and $14.16 \%$, respectively, compared to conventional control treatment with no biochar (SBCK). The numbers of bacterial and fungal operational taxonomic units (OUT) in SD and SY were increased, respectively, compared to that of SBCK. The relationship between soil bacteria and fungi in the biochar-treated groups was stronger than that in the SBCK. The bacterial and fungal populations were correlated with soil nutrients, which suggested that the impacts of biochar on the soil bacteria and fungi community were indirectly driven by alternation of soil nutrient characteristics. The addition of two types of biochar altered the soil microbial community structure and the effect of rice straw biochar treatment on SD was more pronounced. This study aimed to provide a reference and basic understanding for albic soil improvement by biochar, with good application prospects.

Keywords: biochar; albic soil; bacteria; fungi; community structure

\section{Introduction}

Albic soil is a low-yielding soil that possesses obstacles and exists widely throughout the world. There are 32 countries or regions throughout the world that exhibit similar distributions of albic soil, and the total area of albic soil in China is approximately 5.273 million ha [1]. Due to the severe problems caused by dense physical structure, poor nutrient content, and low biological activity, albic soil has been characterized as a lowyielding soil $[1,2]$. It is therefore of great strategic significance to improve low-yielding albic soil to ensure food security. 
Microorganisms can improve soil fertility and productivity by participating in the degradation of organic matter, the formation of humus, the transformation of nutrients, and the cycles of carbon, nitrogen, phosphorus, and other elements [3,4]. The microbial community structure is closely related to soil quality and is extremely sensitive to changes in the living environment [5]. Microbial diversity and community structure can be used as important indicators for assessing soil health status [6]. Plant-growth-promoting rhizobacteria (PGPR) are considered beneficial microorganisms to be used as biofertilizer to promote plant growth and crop yield [7]. The PGPR in the soil act as biochemists, which can influence soil $\mathrm{pH}$, contribute to plant biomass, increase enzyme activity, and improve mineralization $(\mathrm{C}, \mathrm{N})$ processes [8]. Various genera of rhizobacteria such as Pseudomonas, Azospirillum, Azotobacter, Klebsiella, Enterobacter, Alcaligenes, Arthrobacter, Burkholderia, Bacillus, and Serratia have been investigated to improve the growth and productivity of various plants $[9,10]$.

Biochar is the carbon-rich product obtained from the thermochemical conversion of biomass under oxygen-limited conditions [11-13]. Many researchers have reported that biochar contains high levels of carbon and has a structure with physicochemical properties, including a well-developed pore structure, huge surface area, high degree of stability, great adsorption properties, and abundant nutrients that are beneficial to crop yield [14]. Biochar such as rice straw biochar can directly import N, P, K, and Si into this soil [15,16]. The corn biochar reduced the soil bulk density and improved the soil $\mathrm{pH}$, total porosity, aggregate stability, and maximum field capacity during the critical period of soybean growth with a high water requirement [14]. Biochar acts as a conditioner to enhance soil physicochemical properties, a nutrient source for plants, and a carbon source, and a suitable environment for PGPR and indigenous microbes to enhance their growth promotion activities [17].

The biochar provides a good "shelter" for the habitat and for reproduction of microorganisms, and it also reduces survival competition among microorganisms [18-20]. The biochar affects soil microbial growth, diversity, and community compositions by directly providing growth promoters for soil biota or indirectly changing soil basic properties. The porous structure, labile $\mathrm{C}$, high $\mathrm{pH}$, and electrochemical properties of biochar play an important role in determining soil microbial abundance and communities and their mediated N and P cycling processes [19]. However, some studies have indicated that biochar has no effect on the overall microbial community structure [21]. The effects of biochar on microbial community structure are related to the properties of biochar and also to climatic conditions, crops, soil texture, and soil moisture [22].

The effects of biochar on soil microbial community structure have been studied in various soil types $[21,23,24]$. However, there are few reports examining the effect of biochar on the microbial community structure of low-yielding albic soil in Northeast China. Improving the microbial community structure of low-yielding albic soil is of great significance for increasing soil fertility. In this study, rice and corn straw biochar were selected for a pot experiment, and high-throughput sequencing technology was used. The effects of biochar on the diversity of bacteria and fungi in the rice root zone were investigated to reveal the changes in soil microbial community structure in the root zone after application of biochar to ultimately provide a theoretical basis for the improvement of low-yielding albic soil.

\section{Results and Discussion}

\subsection{Influence of Biochar on the Nutrient Content of Albic Soil}

The abundant organic carbon and minerals in biochar are also beneficial for increasing soil organic carbon content [15]. As presented in Table 1, SD and SY increased their soil organic matter content at the rice maturity stage by $1.05 \%$ and $1.31 \%$, respectively, compared to that of SBCK. This may be due to the ability of biochar to adsorb unstable organic carbon through its surface, inhibit organic carbon mineralization, and promote the polymerization of adsorbed organic molecules to form organic matter [15]. Biochar contains a high carbon content $(50.6 \%)$ and thus directly increases the soil organic matter 
content when applied to soil [2]. In this study, the total C content of corn stalk biochar was $50.60 \%$, and the total $\mathrm{C}$ content of rice straw biochar was 51.41\%. Moreover, biochar can release dissolved organic carbon (OC) [15].

Table 1. Effects of biochar on the soil nutrient content in the rice maturation stage.

\begin{tabular}{|c|c|c|c|c|c|c|c|c|}
\hline & $\mathrm{pH}$ & $\begin{array}{l}\text { Organic } \\
\text { Matter } \\
(\mathrm{OC}) \\
(\mathrm{g} / \mathrm{kg})\end{array}$ & $\begin{array}{c}\text { Alkali- } \\
\text { Hydrolyzed } \\
\text { Nitrogen } \\
\text { (AN) (mg/kg) }\end{array}$ & $\begin{array}{c}\text { Available } \\
\text { Phosphorus } \\
\text { (AP) (mg/kg) }\end{array}$ & $\begin{array}{c}\text { Available } \\
\text { Potassium } \\
\text { (AK) } \\
\text { (mg/kg) }\end{array}$ & $\begin{array}{c}\text { Total } \\
\text { Nitrogen } \\
(\mathrm{TN}) \\
(\mathrm{g} / \mathrm{kg})\end{array}$ & $\begin{array}{l}\text { Total } \\
\text { Phosphorus } \\
\text { (TP) (g/kg) }\end{array}$ & $\begin{array}{c}\text { Total } \\
\text { Potassium } \\
\text { (TK) (g/kg) }\end{array}$ \\
\hline SBCK & $6.80^{a}$ & $38.27^{\mathrm{a}}$ & $147.67^{\mathrm{c}}$ & $57.20^{b}$ & $121.00^{b}$ & $1.85^{\mathrm{a}}$ & $1.04^{\mathrm{a}}$ & $17.33^{a}$ \\
\hline SD & $6.30^{a}$ & $38.67^{\mathrm{a}}$ & $166.67^{a}$ & $62.47^{\mathrm{a}}$ & $126.00^{a}$ & $1.94^{\mathrm{a}}$ & $1.08^{\mathrm{a}}$ & $17.40^{\mathrm{a}}$ \\
\hline SY & $6.60^{a}$ & $38.77^{a}$ & $158.67^{b}$ & $62.13^{a}$ & $104.67^{c}$ & $1.93^{\mathrm{a}}$ & $1.13^{\mathrm{a}}$ & $18.27^{a}$ \\
\hline
\end{tabular}

Note: SBCK: conventional control treatment with no biochar; SD: rice straw biochar; SY: corn straw biochar; ${ }^{\text {a-c }}$ Columns reporting different letters are significantly different at $p<0.05(n=3$, LSD test).

Biochar application has been shown to significantly improve chemical properties of problem soils. The previous findings strongly indicate that biochar amendment altered the chemical properties, such as soil CEC, pH, soil TN, and AK contents [14,16,25]. Biochar applications can enhance the status of nutrients, especially $\mathrm{N}$ [26]. Some previous studies have noted the positive effects of biochar on soil inorganic $\mathrm{N}[27,28]$. In this study, the content of alkali-hydrolyzed nitrogen (AN) in SD and SY was increased by $12.87 \%$ and $7.45 \%$, respectively, compared to that in SBCK. The total nitrogen content (TN) of SD and SY was increased by $4.87 \%$ and $4.33 \%$, respectively, compared to that of SBCK. This may be related to the following reasons. The biochar addition stimulated the abundance and growth of soil $\mathrm{N}$-fixing bacteria [24], thereby increasing soil $\mathrm{N}$ nitrification and soil $\mathrm{NH}_{4}{ }^{+}$content [28]. Moreover, the increased soil $\mathrm{NO}_{3}{ }^{-}$from the biochar addition may have occurred because the biochar promoted soil $\mathrm{N}$ mineralization and decreased soil $\mathrm{N}$ leaching [26].

In our study, the content of available phosphorus (AP) in SD and SY was increased by $9.21 \%$ and $8.62 \%$, respectively, compared to that of SBCK. The total phosphorus (TP) content of SD and SY was increased by $3.19 \%$ and $8.63 \%$, respectively, compared to that of SBCK. The total potassium (TK) content of SD and SY was increased by $0.38 \%$ and $5.38 \%$, respectively, compared to that of SBCK. The improvement in soil fertility was partly dependent on the nutrient supply obtained from the biochar addition [29]. Moreover, biochar possesses a rich pore structure and exhibits strong adsorption performance, and it can store nutrients and release nutrients slowly in the soil [30]. Additionally, the improved soil properties (e.g., the increased aggregation capacity and water storage capacity), which were favorable for increasing nutrient contents and decreasing nutrient leaching [31] also led to elevated soil fertility. The improved microbial activity after the biochar addition could accelerate nutrient release to the soil and elevate the nutrient content [32].

The results revealed that the application of rice straw biochar (SD) could increase the soil available potassium (AK) content; however, corn straw biochar (SY) exerted a certain inhibitory effect on the soil AK content, thus indicating that the effects of biochar derived from different sources on the soil AK content were different.

\subsection{Depth Assessment of Soil Sample Sequencing}

Using Illumina high-throughput sequencing, nine fungal samples were sequenced, and 684,677 pairs of reads were obtained. A total of 624,238 clean tags were generated after double-ended reads assembly and filtration, and each sample generated at least 55,249 clean tags. The average number of clean tags was 69,360 . A total of 589,679 pairs of reads were obtained by sequencing nine bacterial samples. A total of 506,522 clean tags were generated after stitching and filtering of double-ended reads, and each sample generated at least 37,163 clean tags with an average of 56,280 clean tags. 
Sequencing sequences were randomly selected, and a curve was constructed by combining the number of sequences extracted with the number of OTUs that they could represent [18]. The OTU was clustered at the $97 \%$ similarity level, and the dilution curves of each sample were generated (Figure 1). As presented in Figure 1, the curves of the bacteria and fungi gradually became flattened, thus indicating a reasonable sequencing quantity.

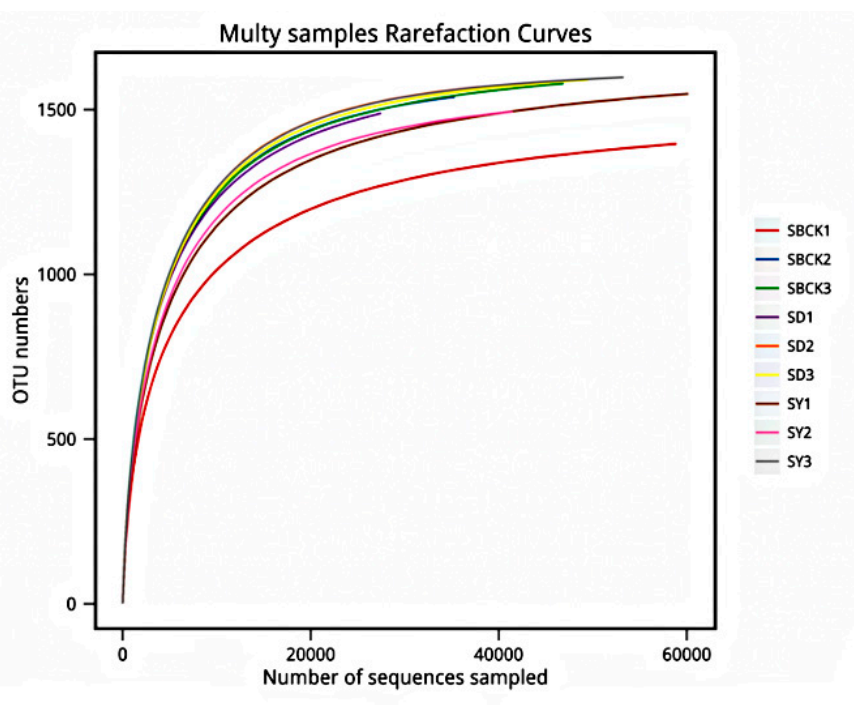

(A)

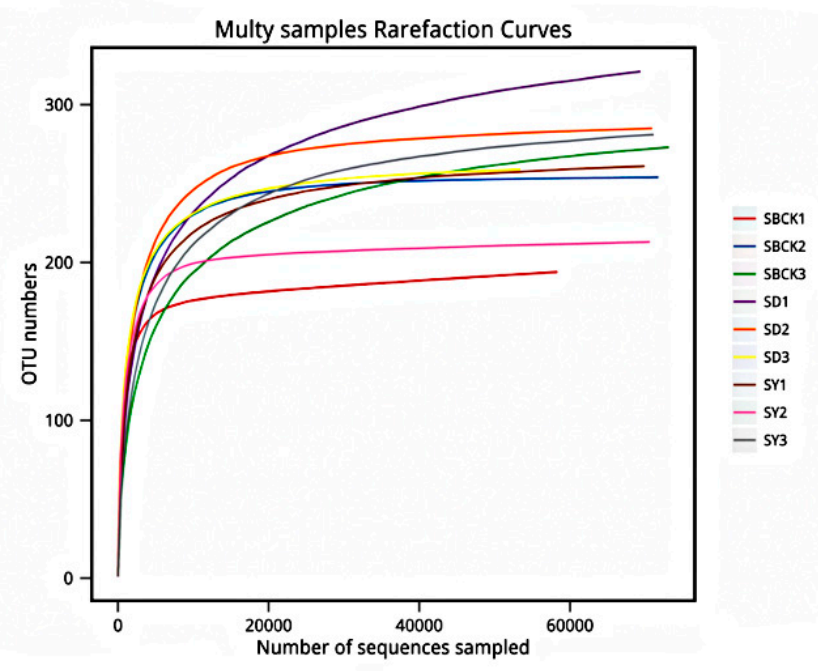

(B)

Figure 1. Bacterial (A) and fungal (B) rarefaction curves from different soil samples (SBCK: conventional control treatment with no biochar; SD: rice straw biochar; SY: corn straw biochar). Note: OUT: operational taxonomic units.

\subsection{Effects of Biochar on the Abundance and Diversity of Soil Bacterial and Fungal Communities}

Changes in soil microbial abundance as a result of biochar addition have been an area of great concern. The ACE and Chao indices reflect the species abundance of the community $[33,34]$. In this study, as presented in Table 2, biochar increased the ACE and Chao indices of soil bacteria. Compared to SBCK, the ACE indices of SD and SY of bacteria were increased by $3.10 \%$ and $2.06 \%$, and the Chao indexes of SD and SY of bacteria were increased by $3.25 \%$ and $2.26 \%$, respectively. The results revealed that the fungi ACE and Chao indices of SD were increased by $7.86 \%$ and $14.16 \%$, respectively, compared to SBCK. This may be due to the abundant pore structure of biochar itself that provides a good "shelter" for the habitat and the reproduction of microorganisms by protecting them from adverse effects such as invasion and dehydration while at the same time reducing the survival competition among microorganisms [33]. Biochar amendment increases soil microbial abundance largely due to a direct result of the utilization of labile $\mathrm{C}$ in biochar and a small amount of nutrients by soil microorganisms [34]. The albic soil in this experiment is poor in nutrients and compact in physical structure. Biochar can indirectly affect the composition of the soil microbial community by improving soil properties, such as the changes of soil $\mathrm{pH}$, adhesion, etc. [34]. 
Table 2. The abundance and diversity of OTUs from soil samples where biochar was applied.

\begin{tabular}{|c|c|c|c|c|c|c|c|c|}
\hline Treatment & $\begin{array}{c}\text { ACE } \\
\text { Index }\end{array}$ & $\begin{array}{l}\text { Chao } \\
\text { Index }\end{array}$ & $\begin{array}{l}\text { Simpson } \\
\text { Index }\end{array}$ & $\begin{array}{l}\text { Shannon } \\
\text { Index }\end{array}$ & $\begin{array}{c}\text { ACE } \\
\text { Index }\end{array}$ & $\begin{array}{l}\text { Chao } \\
\text { Index }\end{array}$ & $\begin{array}{l}\text { Simpson } \\
\text { Index }\end{array}$ & $\begin{array}{l}\text { Shannon } \\
\text { Index }\end{array}$ \\
\hline & \multicolumn{4}{|c|}{ Bacterial (V3 + V4) } & \multicolumn{4}{|c|}{ Fungal (ITS1) } \\
\hline SBCK & $1555.28^{a}$ & $1569.04^{\mathrm{a}}$ & $0.01^{\mathrm{a}}$ & $6.02^{a}$ & $278.18^{a b}$ & $269.35^{a b}$ & $0.12^{a b}$ & $3.34^{\mathrm{a}, \mathrm{b}}$ \\
\hline SD & $1603.53^{a}$ & $1619.97^{a}$ & $0.01^{\mathrm{a}}$ & $6.05^{\mathrm{a}}$ & $300.04^{a}$ & $307.49^{\mathrm{a}}$ & $0.08^{b}$ & $3.47^{\mathrm{a}}$ \\
\hline SY & $1587.25^{a}$ & $1604.48^{\mathrm{a}}$ & $0.01^{\mathrm{a}}$ & $6.00^{\mathrm{a}}$ & $262.53^{b}$ & $262.74^{b}$ & $0.14^{\mathrm{a}}$ & $3.11^{b}$ \\
\hline
\end{tabular}

Note: SBCK: conventional control treatment with no biochar; SD: rice straw biochar; SY: corn straw biochar; ${ }^{\text {a-b }}$ : columns reporting different letters are significantly different at $p<0.05$ ( $n=3$, LSD test); ITS1: internal transcribed spacer-1 region.

However, different types of straw biochar had different effects on fungal abundance. The corn straw biochar (SY) reduced fungal abundance, the SY reduced the ACE index and Chao index of fungi to levels that were $5.63 \%$ and $2.45 \%$ lower, respectively, than that of SBCK. This may be due to the alkaline nature of biochar, as an increase in soil pH reduces the abundance of fungi [21]. The $\mathrm{pH}$ values of rice straw biochar and corn straw biochar adopted in this study are 7.87 and 8.50 respectively. The high $\mathrm{pH}$ value of corn straw biochar may inhibit the abundance of fungal community in albic soil. The corn straw biochar is rich in mineral elements and sufficient nutrients and can adversely affect the growth of mycorrhiza, and high salt content may inhibit the growth and reproduction of mycorrhiza in the soil [23]. In addition, the corn straw biochar may not provide a sufficient number of pores that are suitable for fungal survival [19].

Previous studies have indicated that biochar amendment differs in its effects on bacterial and fungal diversity. For example, Shuailin Li et al. (2020) reported that bacterial and fungal alpha diversity hardly changed after two years of addition of biochar alone or combined with $\mathrm{N}$ fertilizer. Hu et al. (2014) reported that bacterial diversity increased but fungal diversity decreased with short-term biochar addition in a red oxidized loam soil [35]. In this study, biochar had no significant effect on bacterial community diversity. The SD increased fungal community diversity, but SY decreased fungal community diversity. The Shannon index of fungi treated with SD was increased by $3.84 \%$ compared to SBCK. However, the Shannon index of fungi in SY was decreased by $6.99 \%$ compared to SBCK. This may be due to the fact that the diversity of microorganisms is jointly determined by species richness and evenness, and this may vary owing to the proportion of richness and evenness [36].

Different materials of biochar possess certain differences in composition and structure that exert different effects on soil physical and chemical properties and thus exert different effects on microbial community structure diversity [37].

The addition of two types of biochar altered the soil microbial communities, and the effect of rice straw biochar treatment on SD was more pronounced. This may be due to the rice straw biochar having better adaptability to the microbial population in albic soil types. Therefore, in the process of recycling agricultural waste into biochar, the original crops under specific soil types should be given priority.

\subsection{Effects of Biochar on the Relative Abundance of Bacteria and Fungi in Root Zone Soil}

Many studies have demonstrated that biochar has an impact on bacterial and/or fungal community compositions on short- or long-term scales [33,38]. However, the changes in community composition caused by the biochar remain unclear. Figure 2 presents the bar chart for soil bacteria and fungi at the level of phylum classification. According to Figure 2A, the bacteria present in soil samples include Proteobacteria, Acidobacteria, Chloroflexi, Verrucomicrobia, Bacteroidetes, Gemmatimonadetes, and other bacteria groups. Proteobacteria, Acidobacteria, Chloroflexi, and Verrucomicrobia exhibit relatively high abundances of $30.69 \% \sim 34.97 \%, 22.20 \% \sim 24.02 \%, 9.04 \% \sim 11.68 \%$, and $8.64 \% \sim 10.07 \%$, while all other types of bacteria exhibit a total abundance of $74.46 \% \sim 76.40 \%$. 

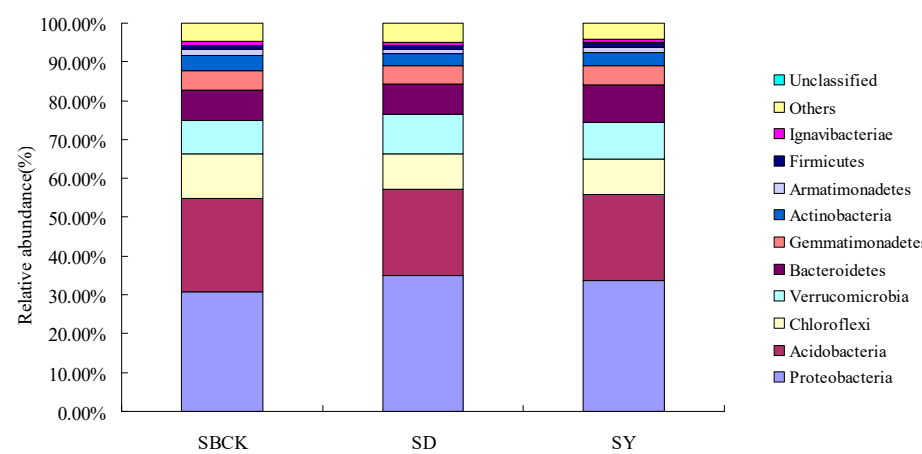

(A)

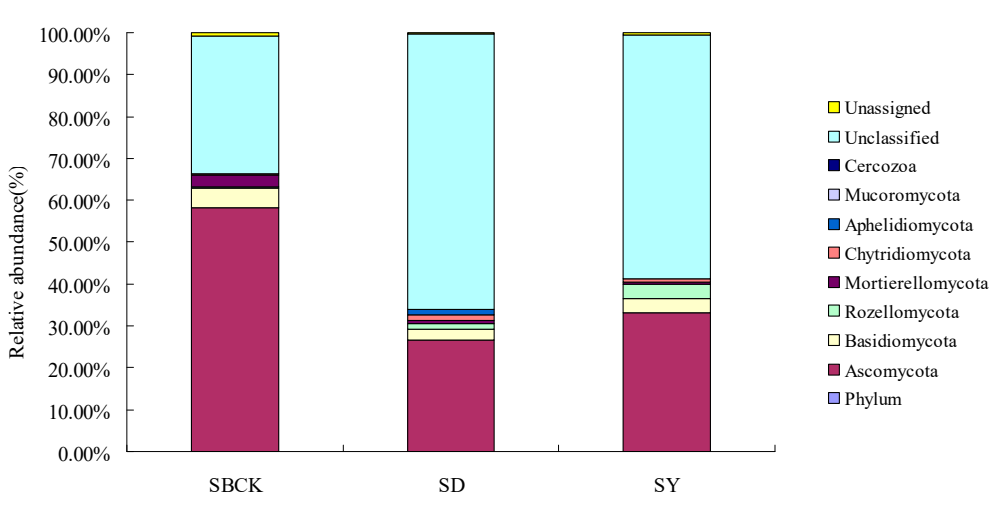

Figure 2. Changes in the relative abundance of soil bacterial species at phylum level (A) and fungal species at phylum (B) level with biochar applied (SBCK: conventional control treatment with no biochar; SD: rice straw biochar; SY: corn straw biochar).

As presented in Figure 2A, biochar increased the relative abundance of Proteobacteria, Verrucomicrobia, and Bacteroidetes. Proteobacteria are the largest group of bacteria. Compared to that of SBCK, the relative abundance of Proteobacteria in SD and SY was increased by $13.95 \%$ and $9.94 \%$, respectively. Proteobacteria accounted for the largest proportion in the soil in terms of community composition and relative abundance, and this is consistent with the conclusions of previous studies $[39,40]$. This is due to the fact that the Proteobacteria is a eutrophic bacterium [41], and biochar application has been shown to significantly improve nutrient properties of albic soils (Table 1), leading to an increase in the abundance of Proteobacteria.

The relative abundance of Verrucomicrobia in SD and SY was increased by $16.57 \%$ and $8.46 \%$ compared to SBCK. Biochar may increase the relative abundance of Verrucomicrobia by increasing soil carbon content and adjusting soil $\mathrm{pH}$ [42]. In this study, SD and SY increased soil organic matter content by $1.05 \%$ and $1.31 \%$.

The relative abundance of Bacteroidetes in SD and SY was increased by $0.39 \%$ and $23.62 \%$, compared to SBCK. Bacteroidetes is closely associated with the conversion of organic materials such as DNA, proteins, and lipids [42]. As a carbon source, the application of biochar to soil is conducive to the improvement of the relative abundance of Bacteroidetes within the soil.

However, biochar reduced the relative abundance of Acidobacteria, Chloroflexi, Gemmatimonadetes, Actinobacteria, and Armatimonadetes. The relative abundance of Acidobacteria in SD and SY was decreased by $7.08 \%$ and $7.58 \%$, compared to SBCK. Most Acidobacteria are acidophilic bacteria, and their abundance is negatively correlated with soil $\mathrm{pH}$. In an environment possessing a low soil pH, the abundance of Acidobacteria is the highest [43]. Biochar is alkaline, and biochar can reduce the relative abundance of Acidobacteria by regulating soil $\mathrm{pH}$ values. In this study, the albic soil $\mathrm{pH}$ value was 5.35 , and those of corn stalk biochar and rice straw biochar were 8.50 and 7.87.

Acidobacteria and Chloroflexi belong to the oligotrophic microorganism group [44,45], and their growth rate is inhibited and their relative abundance is reduced in the eutrophic 
environment of biochar. The relative abundance of Chloroflexi in SD and SY was decreased by $22.60 \%$ and $21.68 \%$, compared to SBCK. Chloroflexi species are usually predicted to degrade plant compounds with pathways commonly identified for the degradation of cellulose, starch, and long-chain sugars and compete for labile carbon with other organisms [46]. Therefore, the lower relative abundance of Chloroflexi in SD and SY may limit the organic material degradation rate.

The relative abundance of Actinobacteria in SD and SY were decreased. Actinobacteria, as Gram-positive bacteria, play a vital role in organic matter turnover, including the decomposition of cellulose and chitin [47]. The decreased populations of Actinobacteria in SD and SY may symmetrically retard microbial organic matter decomposition, which partly drives the higher soil $\mathrm{CO}_{2}$ emissions [47].

As presented in Figure 2B, fungi present in the soil samples include Ascomycota, Basidiomycota, Rozellomycota, Mortierellomycota, Chytridiomycota, and other fungi. In addition to other fungi whose species have not been determined, the relative abundance of Ascomycota and Basidiomycota were $26.19 \%-58.19 \%$ and $2.19 \%-4.65 \%$, respectively, and these belonged to the dominant fungi with a cumulative sum of $29.17 \%-62.84 \%$.

Biochar increased the relative abundance of Rozellomycota, Chytridiomycota, Apheliidiomycota, and unclassified fungi. This increase in fungal species led to increased competition for energy and nutrients among species [48], resulting in a decrease in the relative abundance of major fungal groups and thus further demonstrated that biochar enriched the community structure of soil fungi.

However, biochar decreased the relative abundance of Ascomycota, Basidiomycota, and Mortierellomycota. Basidiomycota can roughly be divided into the following, saprobic fungi, which decompose organic matter; symbiotic fungi, which form a mutualistic relationship with other organisms; pathogenic or parasitic fungi, which infect plants, animals, and even other fungi [49]. The relative abundance of Basidiomycota in SD and SY was decreased by $43.22 \%$ and $23.46 \%$, respectively, compared to SBCK. Mineralizable C has been reported to significantly decrease the relative abundance of Basidiomycota, and most fungal OTUs from Basidiomycota were assigned as nonsaprotrophs. As a microbial C source, the DOC probably promotes saprotroph growth and enhances their competitive capacity, leading to an overall decrease in diversity and a decline in fungal pathogens [50]. Hence, the decreased relative abundance of Basidiomycota in biochar treatments may be due to biochar increasing the organic matter (Table 1).

Figure 3 presents the bar chart for soil bacteria and fungi at the level of genus classification. As presented in Figure 3A, at the genus level of soil bacteria biochar increased the relative abundance of Sphingomonas, uncultured_bacterium_f_DA101_soil_group, Geobacter, and uncultured_bacterium_f_Gemmatimonadaceae. However, the relative abundances of uncultured_bacterium_f_Acidobacteriaceae_[Subgroup_1], Candidatus_Solibacter, Anaeromyxobacter, uncultured_bacterium_f_Anaerolineaceae, Anaerolinea, and Gemmatimonas were decreased. Bradyrhizobium is widely regarded as a nitrogen-fixing and denitrification bacterium and participates in the nitrogen cycle [51]. In this study, the effect of different kinds of biochar on Bradyrhizobium was inconsistent. The corn stalk biochar (SY) increased the abundance of Bradyrhizobium and rice stalk biochar (SD) decreased. However, the effect of biochar on other PGPR was not detected. The biochar not only improves the physicochemical properties of the soil but also serves as carrier material for PGPR inoculation [9,52], and biochar provides a safer environment against various biological competitors in soil due to porous structure [53,54]. Further research is needed to confirm the biochar with PGPR efficacy in the long-term with respect to albic soil conditions. 


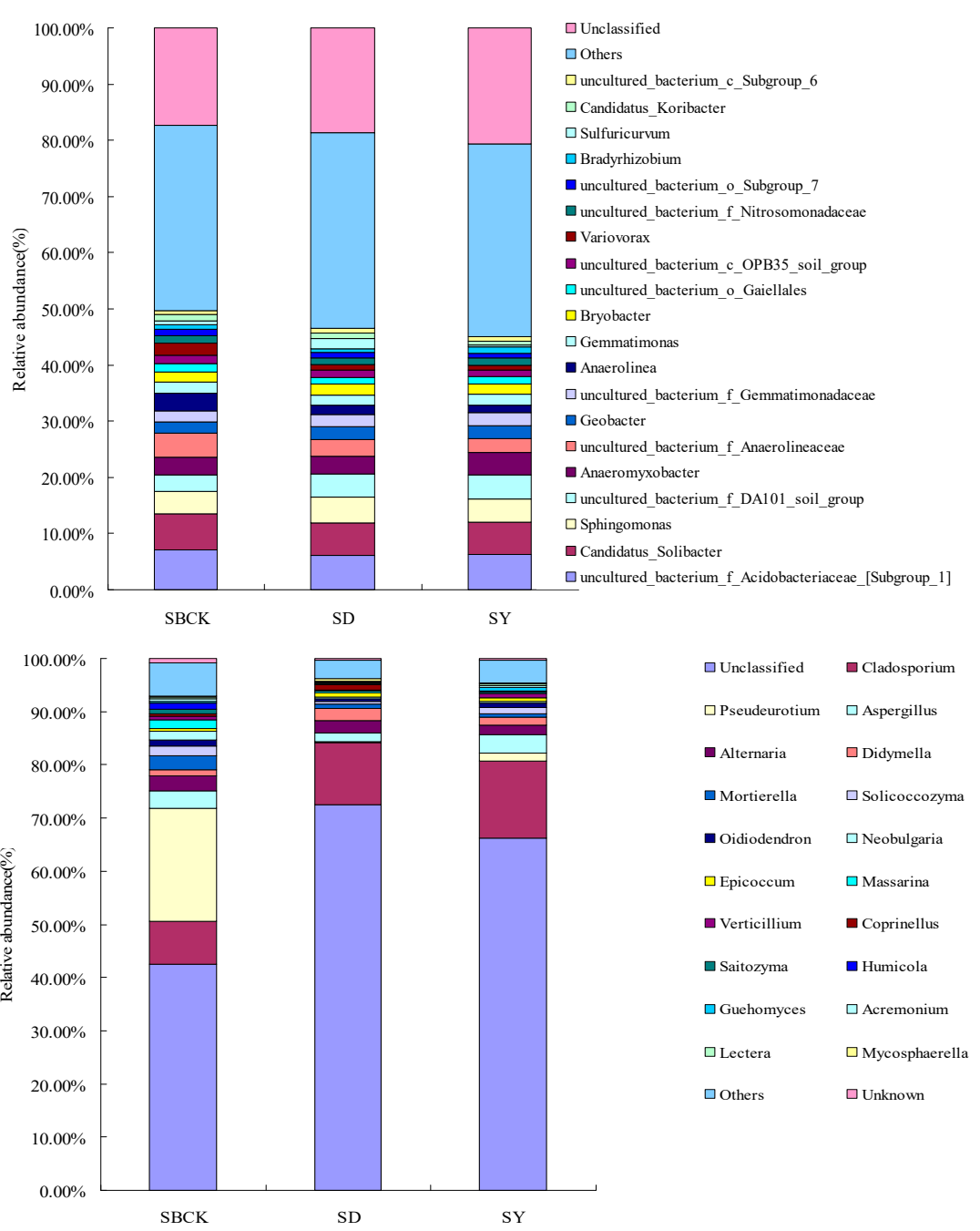

Figure 3. Changes in relative abundance of soil bacterial species at the genus level (A) and fungal species at genus level (B) with biochar applied (SBCK: conventional control treatment with no biochar; $\mathrm{SD}$ : rice straw biochar; SY: corn straw biochar).

As presented in Figure 3B, biochar increased the relative abundance of Cladosporium and Didymella at the genus level of soil fungi. However, the relative abundance of Pseudeurotium, Alternaria, Mortierella, Solicoccozyma, Oidiodendron, and Neobulgaria were decreased.

Mortierella was shown to successfully suppress the occurrence of clubroot disease (caused by Sclerotinia sclerotiorum) [55], which includes fast-growing saprobic fungi that mainly utilize simple soluble substrates and is associated with high cellulose content in the soil [56]. The relative abundances of Mortierella were positively correlated with soil TC content [57]. Yao et al. (2017) showed that biochar had no significant effect on Mortierella abundance. This study showed that biochar reduced the abundance of Mortierella. Although the biochar provided a carbon source for albic soil, it is speculated that the dominant fungi genera in the soil compete for carbon sources, leading to the decrease in Mortierella abundance.

Alternaria is one of the important fungal groups that can cause plant diseases, and nearly $90 \%$ of the reported species of Alternaria fungi in the world can cause field and postnatal losses [58]. The abundance of Alternaria could be reduced by applying cotton stalk biochar in soil not polluted by cadmium [55]. The experiment showed that the abundance of Alternaria was decreased by biochar, and the reduced abundance means that biochar application may be beneficial to the control of crop diseases. The mechanism of biochar inhibition of plant diseases is very complex, including direct inhibition of pathogen growth [59]. 
Significance analysis of inter-group differences revealed that when an LDA value of $>4$ was set, there were few markers with significant differences between different groups of samples. When an LDA value of $>3$ was set, the significant difference markers in soil bacteria were enriched in the SD and SY treatments, and the significant difference markers in SD and SY were 3, while that of SBCK was 0. Significant difference markers in soil fungi were enriched in SBCK and SD treatments, of which nine markers were found for SBCK and two markers were found for SD. This demonstrates that biochar affects the composition of bacteria and fungi within the soil (Figure 4).

\section{Cladogram}

SD

$\square$ a: s_uncultured_bacterium_f_Blastocatellaceae_Subgroup_

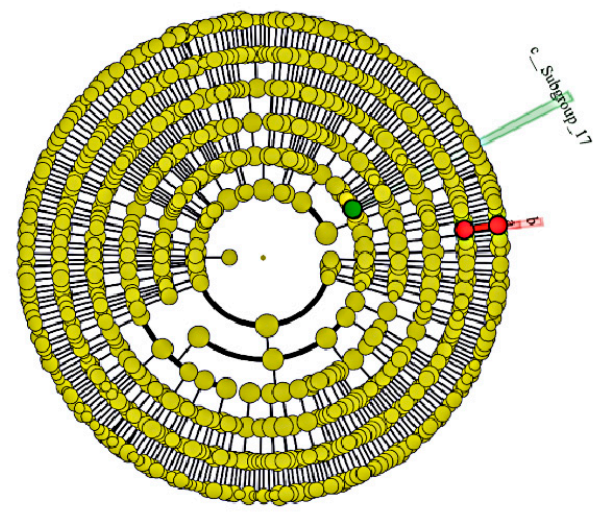

\section{Cladogram}

SBCK

$\mathrm{SD}$
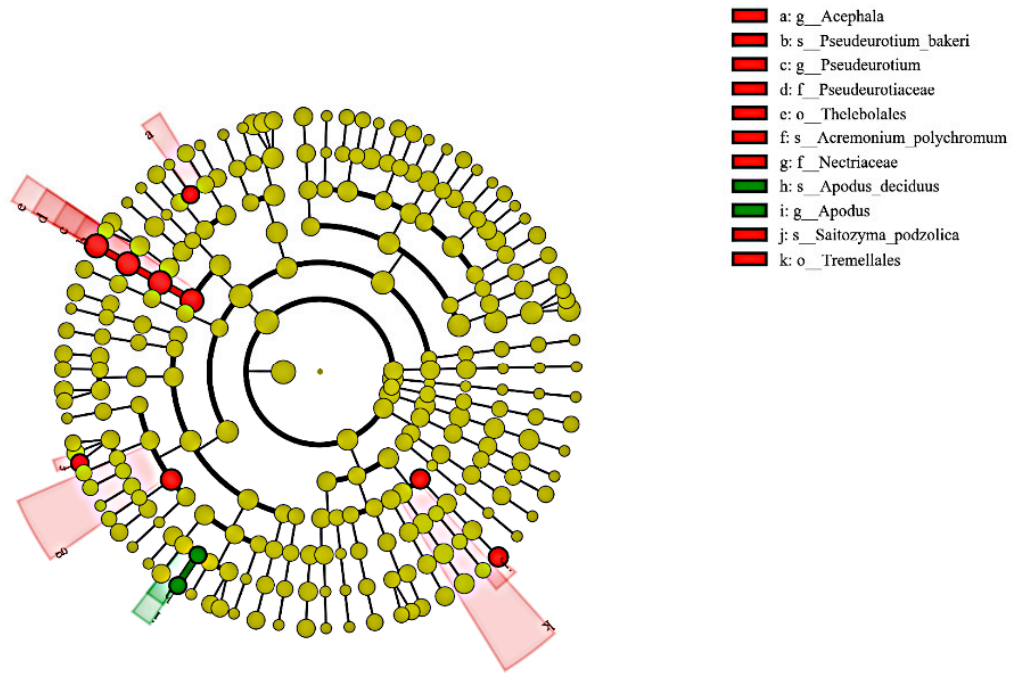

(B)

Figure 4. Significance analysis of differences among different treatment groups. Note: (A) soil bacteria, (B) soil fungi (SBCK: conventional control treatment with no biochar; SD: rice straw biochar; SY: corn straw biochar). 


\subsection{Analysis of Soil Bacteria and Fungi Groups in the Context of Biochar Treatment}

The composition and relative abundance of bacteria and fungi in saline-sodic soil changed after 3 years of applying different dosages of biochar under rice cultivation. The addition of biochar had no significant impact on the bacterial diversity, but the diversity of fungi showed a tendency to decrease [60]. The long-term influence of biochar addition on the fungal community was shown at the genus and OTU levels but not at the phylum level [48]. As indicated in Table 3, biochar increased the number of bacterial OTUs. The numbers of bacterial OTU units in SD and SY were 1549.67 and 1546.67, respectively, and these were increased by $3.01 \%$ and $2.81 \%$, respectively, compared to the value of 1504.33 in SBCK. Biochar increased the number of fungal OUT units, and the number of fungal OUT units in SD and SY were 288.33 and 251.67, respectively. These were increased by $19.97 \%$ and $4.72 \%$ compared to the value of 240.33 in SBCK.

Table 3. Reads for observed soil bacterial and fungal OTUs.

\begin{tabular}{ccccc}
\hline Treatment & $\begin{array}{c}\text { Bacterial (V3 + V4) } \\
\text { OTU Numbers }\end{array}$ & Coverage & $\begin{array}{c}\text { Fungal (ITS1) } \\
\text { OTU Numbers }\end{array}$ & Coverage \\
\hline SBCK & $1504.33^{\mathrm{a}}$ & $0.9973^{\mathrm{a}}$ & $240.33^{\mathrm{b}}$ & $0.9998^{\mathrm{a}}$ \\
SD & $1549.67^{\mathrm{a}}$ & $0.9961^{\mathrm{a}}$ & $288.33^{\mathrm{a}}$ & $0.9997^{\mathrm{a}}$ \\
SY & $1546.67^{\mathrm{a}}$ & $0.9979^{\mathrm{a}}$ & $251.67^{\mathrm{a}, \mathrm{b}}$ & $0.9998^{\mathrm{a}}$ \\
\hline
\end{tabular}

Note: SBCK: conventional control treatment with no biochar; SD: rice straw biochar; SY: corn straw biochar; OUT: operational taxonomic units; $^{\text {a-b }}$ : columns reporting different letters are significantly different at $p<0.05$ ( $n=3$, LSD test); ITS1: internal transcribed spacer-1 region.

Venn diagrams can reflect the number of common and unique OTUs between groups or samples and can intuitively indicate the overlap of OTUs between groups or samples [61]. Apple biochar at $0.5 \%-4 \%$ dosage could significantly increase the number of unique bacteria OTUs and affect the bacteria groups [62], while the number of unique bacterial OTU was one to three times the common OTU numbers, but they had no significant effect on the fungal groups [48]. As presented in Figure 5A, the number of common bacterial OTUs among different treatments was 1624 , the number of unique bacterial OTUs without biochar application (SBCK) was 1, and the numbers of unique bacterial OTUs in biochar treatment of SD and SY were 4 and 3, respectively. The number of common fungal OTUs among the different treatments was 280 , the number of unique fungal OTUs in the absence of biochar (SBCK) was 25, and the numbers of unique fungal OTUs in the biochar treatment of SD and SY were 34 and 32, respectively (Figure 5B). This indicates that biochar can increase the number of unique OTUs of bacteria and fungi in soil and can alter the composition of bacteria and fungi groups. This is due to the ability of biochar to affect soil physical and chemical properties and biological characteristics to thus create a specific microenvironment for microorganisms [63]. 


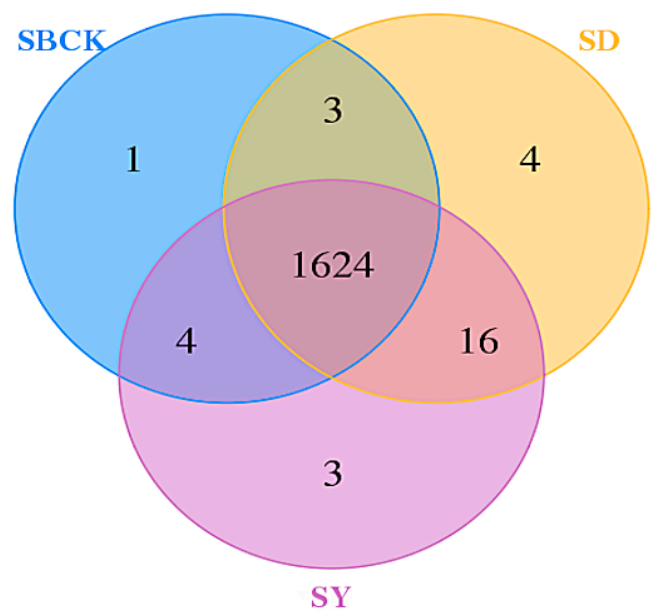

(A)

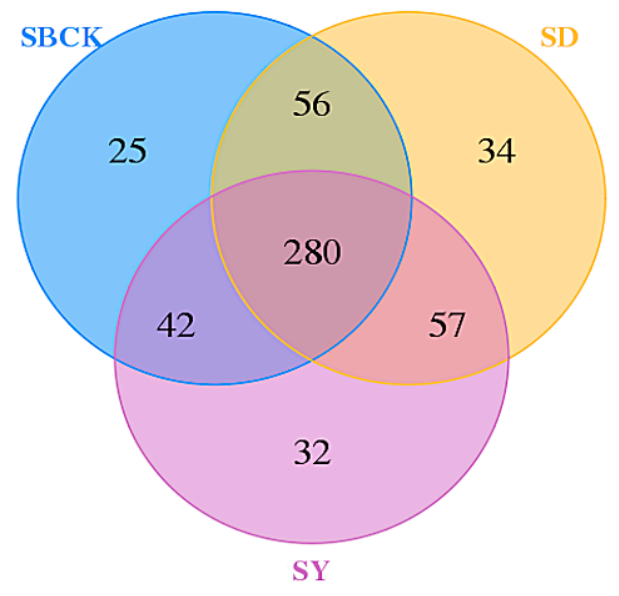

(B)

Figure 5. Venn diagrams of soil bacterial (A) and fungal (B) communities in soil (SBCK: conventional control treatment with no biochar; SD: rice straw biochar; SY: corn straw biochar).

\subsection{Effects of Biochar on the Interaction of Soil Bacteria and Fungi}

In this study, the co-expression analysis based on Python plotting revealed the top 50 different genera with the highest correlation, and these are presented in Figures 6 and 7. The horizontal correlation network diagram of genera revealed that there is significant interaction between different genera (the orange line represents positive correlation, the green line represents negative correlation, the thickness of the line represents the magnitude of the correlation coefficient, and the number of lines represents the close degree of connection between nodes). Figure 6 shows that in the interaction network of major soil bacteria genera, the high relative abundance microorganisms of SBCK were Candidatus_Solibacter, Uncultured_Bacterium_F_Anaerolineaceae, and Uncultured_Bacterium_F_Da101_Soil_Group. The groups with higher relative abundance in SD were uncultured_Bacterium_F_Acidobacteriaceae_[Subgroup_1] and Uncultured_Bacterium_F_Da101_Soil_Group. Those with high relative abundance in SY were Uncultured_Bacterium_F_Acidobacteriaceae_[Subgroup_1], Uncultured_Bacterium_F_Da101_Soil_Group and Anaeromyxobacte R. The degrees of correlation among the bacterial genera were different. Among the SBCK, 38 were negatively correlated, and 29 were positively correlated. Among the SD treatments, 48 were negatively correlated, and 34 were positively correlated. In the SY treatment group, 48 were negatively correlated, and 31 were positively correlated. It can be observed that the correlation of major soil bacteria genera in the biochar treatment group is stronger than SBCK, and the number of positive correlations (orange) in the biochar treatment group was higher than SBCK. 


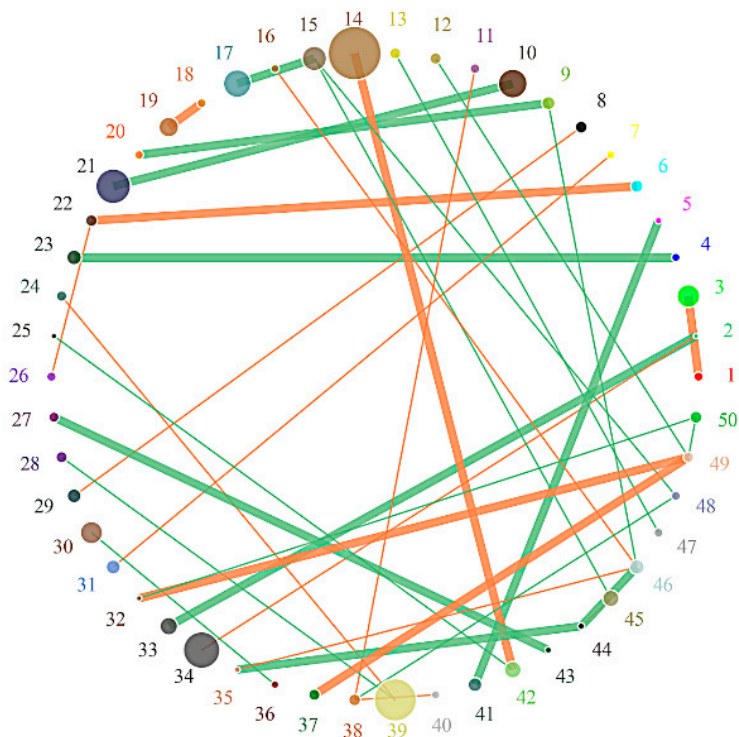

-1: uncultured_bacterium_o_SC-I-84

2: uncultured bacterium $f$ Ruminococcaceae

3: uncultured bacterium $f$ Nitrosomonadaceae

4: Mesorhizobium

5: uncultured_bacterium_c_SB-5

6: Lysobacter

7: Reyranella

8: uncultured_bacterium_p_Parcubacteria

9: uncultured_bacterium_c_Bacteroidetes_vadinHA17

- 10: Geobacter

11: uncultured bacterium $f$ Porphyromonadaceae

12: uncultured bacterium o Chthonomonadales

13: uncultured_bacterium_o_Acidimicrobiales

14: Candidatus_Solibacter

15: uncultured_bacterium_o_Gaiellales

16: BSV13

17: Variovorax

18: uncultured bacterium $f$ Blastocatellaceae_Subgroup

19: Candidatus_Koribacter

20: Arenimonas

O21: Anaeroline

O 22: uncultured bacterium $\mathrm{f}$ Comamonadaceae

O23: uncultured bacterium $f$ Chitinophagaceae

24: Nitrospira

25: Sideroxydans
26: RB41

27: AKIW659

228: uncultured bacterium o C 0119

29: uncultured bacterium_f_Holophagaceae

O30: uncultured_bacterium_o_Subgroup_?

031: uncultured bacterium f BSV26

32: uncultured bacterium $f$ Rhodospirillaceae

33: Bradyrhizobium

O34: uncultured_bacterium_f_DA101_soil_group

35: Blastococcus

O36: uncultured bacterium $f$ Lentimicrobiaceae

37: Denitratisoma

O38: uncultured_bacterium_p_Armatimonadetes

039: uncultured_bacterium_f_Anaerolineaceae

40: Leptolinea

41: Flavisolibacter

42: uncultured_bacterium_c_Subgroup_6

43: Desulfovirga

- 44: uncultured bacterium $\mathrm{f} P 3 \mathrm{OB}-42$

45: uncultured_bacterium_c_S0134_terrestrial_group O46: uncultured_bacterium_f_Rhodocyclaceae

47: Haliangium

48: Blvii28 wastewater-sludge group

49: uncultured bacterium f Draconibacteriaceac

50: uncultured bacterium c SBR2076

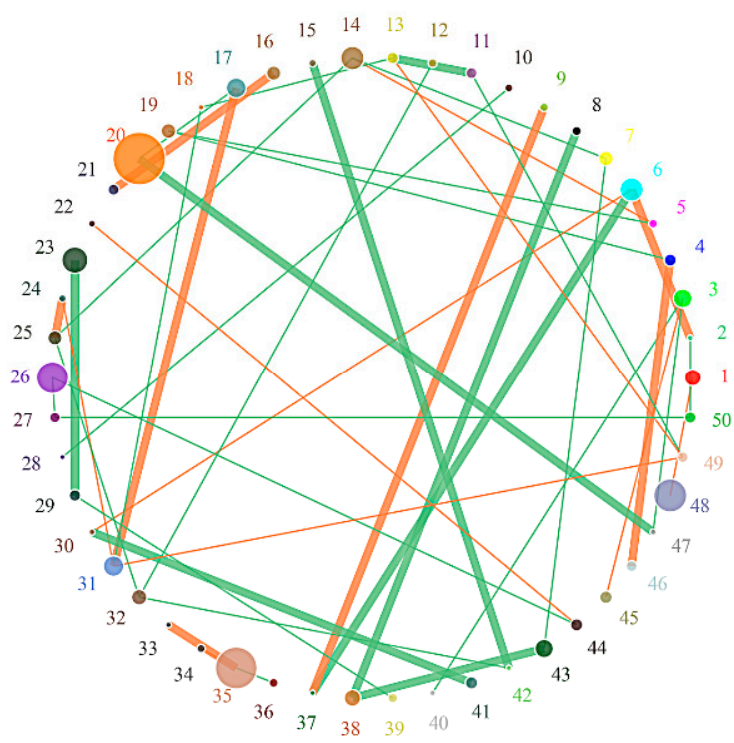

(A)
1: uncultured bacterium $f$ Chitinophagaceae

2: uncultured bacterium $f$ Ruminococcaceae

3: uncultured bacterium p Latescibacteria

4: Lysobacter

5: Reyranella

6: uncultured_bacterium_c_OPB35_soil_group

7: uncultured_bacterium_c_KD4-96

-8: uncultured_bacterium_c_Subgroup_17

9: Phenylobacterium

- 10: uncultured_bacterium_f_Porphyromonadaceae

11: uncultured_bacterium_o_Chthonomonadales

12: Deferrisoma

13: uncultured bacterium o Acidimicrobiales

14: uncultured_bacterium_o_Gaiellales

15: Rhodobacter

16: Rhizomicrobium

17: Variovorax

18: uncultured bacterium $\mathrm{p}$ WS6

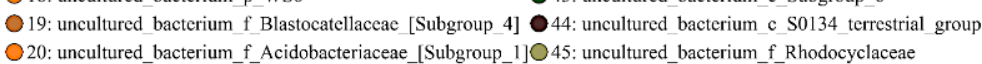

20: uncultured_bacterium_f_Acidobacteriaceae_[Subgroup_1] 45: uncultured_bacterium_f_Rhodocyclaceae

O21: Arenimonas

- 22: CL500-29_marine group

23: Anaerolinea

24: Sideroxydan

O25: uncultured_bacterium_o_SC-I-84
26: uncultured bacterium $f$ Gemmatimonadaceae

27: Nitrospira

28: Acidibacter

29: uncultured bacterium_c TK10

30: Novosphingobium

031: uncultured bacterium_o_Subgroup_7

32: uncultured_bacterium_f_BSV26

O 33: uncultured_bacterium_f_Rhodospirillaceae

34: uncultured bacterium c SJA-15

35: uncultured_bacterium_fDDA101_soil_group

37: uncultured_bacterium o Frankiales

38: Variibacter

39: uncultured bacterium p_Armatimonadetes

40: uncultured_bacterium_o_Lincage_IIb

41: Desulfovibrio

42: uncultured bacterium $f$ Draconibacteriaceae

46: Haliangium

47: uncultured bacterium $f$ Acetobacteraceae

48: Vogesella

49: uncultured_bacterium_f_Gallionellaceae

O50: uncultured_bacterium_c_SBR2076
- 36: uncultured_Acidobacteria_bacterium

(B)

Figure 6. Cont. 


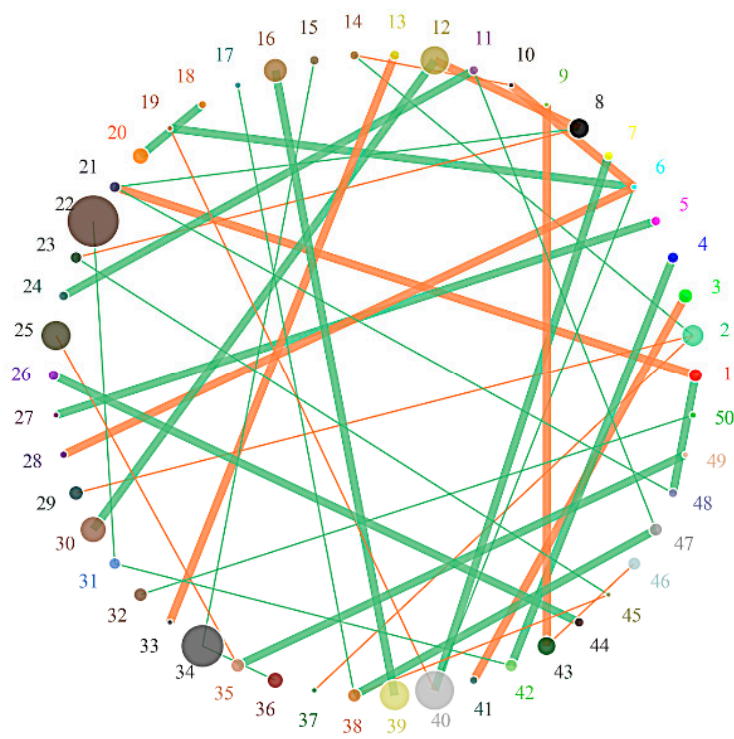

O 1: uncultured_bacterium_c_Bacteroidetes_vadinHA17

2: uncultured_bacterium_f_Nitrosomonadaceae

3: Mesorhizobium

4: Lysobacter

5: Reyranella

6: uncultured bacterium $f$ Ruminococcaceae

7: uncultured bacterium p Parcubacteria

-8: uncultured_bacterium_c_OPB35_soil_group

9: Ruminiclostridium 1

- 10: uncultured_Acidobacteriales_bacterium

11: uncultured bacterium_c_Subgroup_17

12: Gemmatimonas

13: Phenylobacterium

14: Devosia

15: uncultured bacterium o Chthonomonadales

16: uncultured_bacterium_o_Gaiellales

17: Sulfuricurvum

18: uncultured_bacterium_f_Draconibacteriaceae

19: uncultured_bacterium_f_OP'B56

20: uncultured bacterium_p_Latescibacteria

O 21: uncultured_bacterium_f_Blastocatellaceae_[Subgroup_4] 046 : uncultured_bacterium_c_S0134_terrestrial_group

O22: uncultured_bacterium_f_Acidobacteriaceae_[Subgroup_1] $\bigcirc 47$ : uncultured_bacterium_f_Gallionellaceae

O23: uncultured_bacterium_c_TK10

24: uncultured_bacterium_c_SJA-15

25: uncultured bacterium_f_Gemmatimonadaceae
26: Nitrospira

27: uncultured_alpha_proteobacterium

28: RB41

O29: H16

30: Bryobacter

31: Opitutus

32: uncultured bacterium f BSV26

O 33: uncultured bacterium $f$ Rhodospirillaceae

O34: uncultured bacterium f DA10I soil group

35: Pseudolabrys

O36: Candidatus Koribacter

37: Rhodanobacter

38: uncultured_bacterium_f_MNG7

39: Geobacter

40: Anaeromyxobacter

O41: Desulfovibrio

42: Flavisolibacter

44: [Desulfobacterium] catecholicu

48: Haliangium

49: Rhizobium

50: uncultured bacterium $f$ Acetobacteraceae

\section{(C)}

Figure 6. Network of the interactions of the main bacteria genus in soil. Note: (A) SBCK (conventional control treatment with no biochar); (B) SD (rice straw biochar); (C) SY (corn straw biochar).

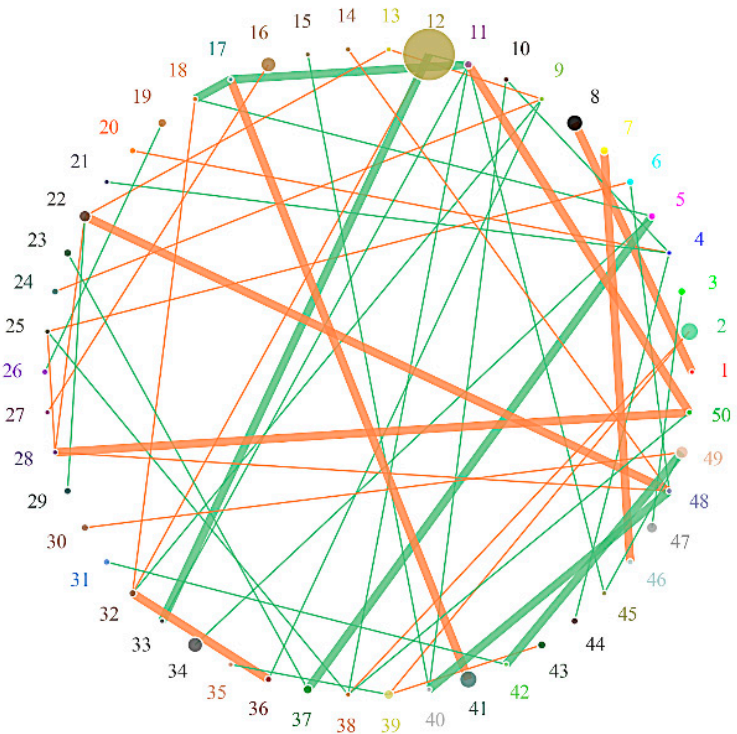

1: Hannaella $\quad$ 26: Coniochaeta

2: Solicoccozyma 27: Nowakowskiella

3: Tetracladium 28 : Metarhizium

4: Mrakia 29: Mycosphaerella

5: Acephala O30: Venturia

6: Pyrenochactopsis 031 : Talaromyces

7: Lectera O32: Scutellinia

8: Neobulgaria O33: Cephalotrichum

9: Moeszionyces O34: Didymella

10: Vishniacozyma O35: Neoascochyta

11: Chaetosphaeria O36: Penicillium

12: Pseudeurotium 37 : Coprinellus

13: Stemphylium 038 : Sonoraphlyctis

14: Leptospora O39: Podospora

15: Collarina 4 40: Archaeorhizomyces

16: Oidiodendron 041 : Massarina

17: Kondoa $\quad$ 42: Schizothecium

18: Fusicolla 43: Dimorphospora

19: Paraphacosphacria 44: Trichoderma

20: Sampaiozyma 45: Ascochyta

21: Cercospora 46: Myxocephala

22: Verticillium 47: Acremonium

23: Nigrospora 48: Aurcobasidium

24: Sporobolomyces $\bigcirc 49$ : Saitozyma

25: Rhodotorula O50: Pseudopithomyces

(A)

Figure 7. Cont. 


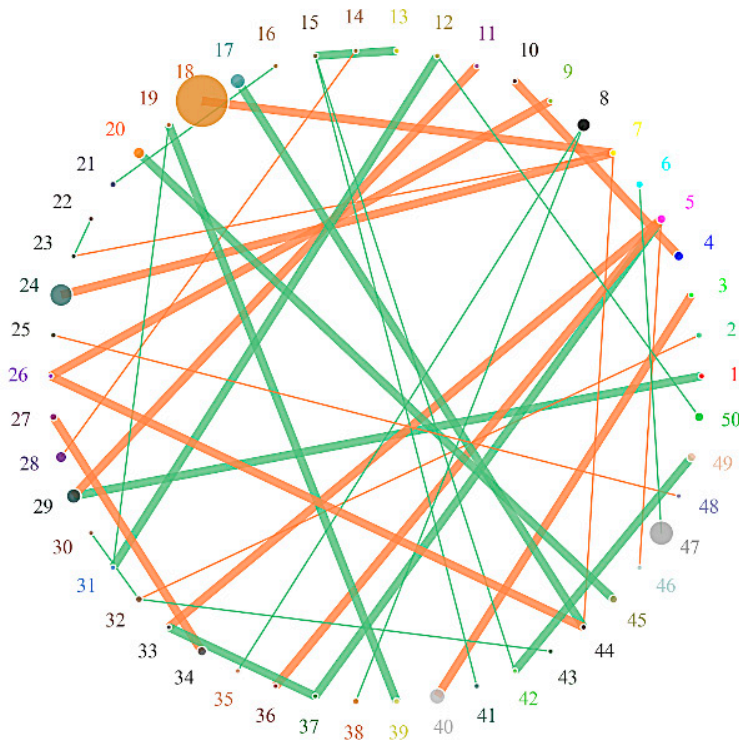

\begin{tabular}{|c|c|}
\hline 1: Conocybe & 26: Cephalotrichum \\
\hline 2: Tetracladium & 27: Neoascochyta \\
\hline 3: Stagonospora & 28: Rhizophydium \\
\hline 4: Lectera & 29: Coprinellus \\
\hline 5: Neobulgaria & 30: Exophiala \\
\hline 6: Chaetosphaeria & 31: Ramularia \\
\hline 7: Pseudeurotium & 32: Podospora \\
\hline 8: Oidiodendron & 33: Archaeorhizomyces \\
\hline 9: Cystobasidium & 34: Massarina \\
\hline 10: Naganishia & 35: Filobasidium \\
\hline 11: Kondoa & 36: Keissleriella \\
\hline 12: Fusicolla & 37: Serendipita \\
\hline 13: Sampaiozyma & 38: Dimorphospora \\
\hline 14: Cercospora & 39: Arnium \\
\hline 15: Nigrospora & 40: Epicoccum \\
\hline \multicolumn{2}{|c|}{ 16: Xenopolyscytalum 41: Trichoderma } \\
\hline 17: Mortierella & 42: Myxocephala \\
\hline 18: Cladosporium & 43: Microdochium \\
\hline 19: Candida & 44: Helicodendron \\
\hline 20: Mycosphaerella & 45: Acremonium \\
\hline 21: Venturia & 46: Penicillifer \\
\hline 22: Purpureocillium & 47: Alternaria \\
\hline 23: Sarocladium & 48: Bocremia \\
\hline 24: Aspergillus & 49: Sporobolomyces \\
\hline 25: Phaeosphaeri & 50: Verticillium \\
\hline
\end{tabular}

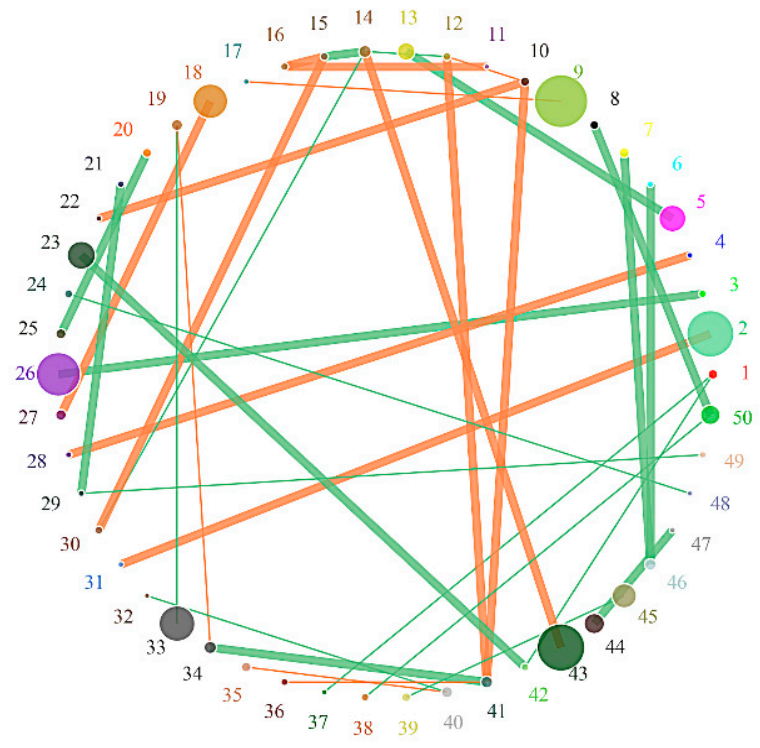

1: Tetracladium 2: Solicoccozyma

3: Dioszegia

4: Stagonospora

5: Lectera

6: Mocsziomyces

7: Chloridium

8: Humicola

9: Pseudeurotium

10: Stemphylium

11: Phallus

12: Wallemia

13: Penicillium

14: Trichocladium

15: Kazachstania

16: Occultifu

17: Edenia

18: Guehomyces

19: Angulomyces

20: Rhodotorul

21: Agaricus

22: Erythrobasi

23: Venturia

24: Phaeosphaer

25: Papiliotrema
26: Didymella

27: Neoascochyta

28: Rachicladosporium

29: Pyrenochaetopsis

30: Kondoa

31: Gibberclla

32: Articulospora

33: Verticillium

34: Podospora

35: Archaeorhizomyces

- 36: Massarina

37: Filobasidium

38: Fusicolla

39: Arnium

40: Trichoderna

41: Plectosphaerella 42: Holtermanniella

43: Alternaria

- 44: Acremonium

45: Saitozyma

O46: Lichtheimia

47: Stagonosporopsi

48: Boeremia

49: Sampaiozyma

50: Sporobolomyce

(C)

Figure 7. Network of interactions of the main fungi genus in soil. Note: (A) SBCK (conventional control treatment with no biochar); (B)SD: (rice straw biochar); (C) SY: (corn straw biochar).

As presented in Figure 7, in the interaction network of major soil fungi genera, Pseudeurotium exhibited the highest relative abundance in SBCK, while Cladosporium, Aspergillus, and Alternaria exhibited the highest relative abundance in SD. The high relative abundances in SY were Pseudeurotium, Didymella, Alternaria, and Solicoccozyma. The degrees of correlation among the fungal genera were different. Among SBCK, 39 fungal genera were negatively correlated, and 30 fungal genera were positively correlated. There were 47 negative correlations and 41 positive correlations among SD treatments. In the SY treat- 
ment group, 43 exhibited a negative correlation, and 35 possessed a positive correlation. It can be observed that the correlation of soil fungal genera in the biochar treatment group was stronger than SBCK, and the number of positive correlations (orange) in the biochar treatment group was significantly higher than that in the SBCK group. Biochar increases the interaction level between microorganisms, and this may affect the complexity of the network structure. This indicates that biochar application can not only alter the microbial community structure but also change the overall microbial interaction.

\subsection{Correlation Analysis of Soil Microbial Community and Nutrients}

Soil physical and chemical properties such as $\mathrm{pH}$, water content, organic matter, and soil nutrients are important factors that affect the soil microbial community [24]. As shown in Figure 8, the RDA results in this study revealed that $\mathrm{pH}$, organic matter, $\mathrm{AN}, \mathrm{AP}$, and AK all exerted a significant influence on soil bacteria and fungi and exhibited a significant correlation, and these results were similar to those of previous studies [64,65]. $\mathrm{pH}$ exerts a large influence on the suitable living environment for microorganisms [66]. Organic matter content $(\mathrm{OC})$ is the most important measurement index of soil nutrients, and nitrogen is an essential nutrient for microorganisms [67].

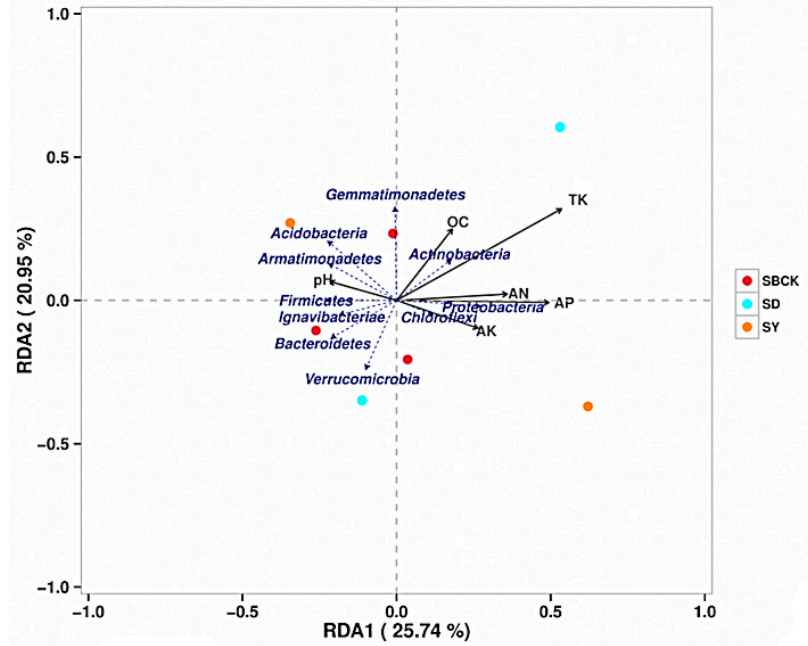

(A)

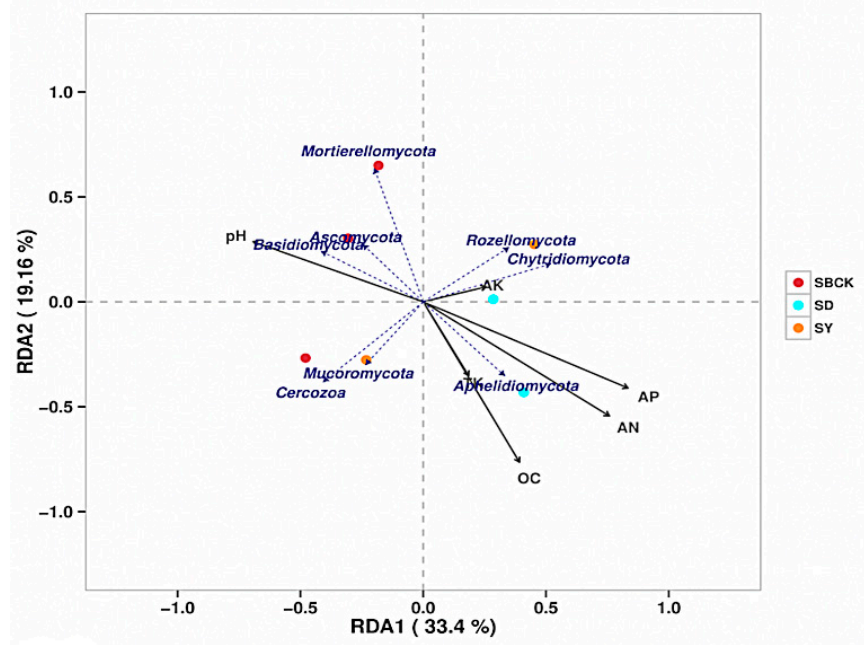

(B)

Figure 8. RDA analysis of the effects of soil nutrients on changes in bacterial community (A) and fungal community (B) structure. Note: SBCK (conventional control treatment with no biochar); SD (rice straw biochar); SY: (corn straw biochar); TK: total potassium; OC: organic matter content; AN: available nitrogen; AP: available phosphorus; AK: available potassium.

Redundancy analysis revealed that the main bacterial populations in the soil were correlated with the soil nutrients (Figure 8A). The relationship between rays in the figure is represented by the included angles, with obtuse angles representing negative correlation and acute angles representing positive correlation. The RDA analysis revealed that the eigenvalues of the two main axes were $25.74 \%$ and $20.95 \%$, respectively. Among these, TK, $\mathrm{OC}$, and AN were positively correlated with Actinobacteria and were distributed in the first quadrant. TK, OC, and AN were negatively correlated with Ignavibacteriae, Bacteroidetes, and Verrucomicrobia, and were concentrated in the third quadrant. AK was positively correlated with Chloroflexi and distributed in the fourth quadrant, while $\mathrm{pH}$ was positively correlated with Acidobacteria and Armatimonadetes and distributed in the second quadrant. Soil TK was the environmental factor that possessed the highest explanatory degree.

The major fungal populations in the soil were correlated with soil nutrients (Figure 8B). The RDA analysis revealed that the two main axis eigenvalues were $33.4 \%$ and $19.16 \%$, respectively. AK was positively correlated with Rozellomycota and Chytridiomycota and was 
distributed in the first quadrant. AK was negatively correlated with Mortierellomycota and Cercozoa, which were distributed in the third quadrant. AP, AN, and OC were positively correlated with Aphelidiomycota and were distributed in the fourth quadrant. $\mathrm{pH}$ was positively correlated with Mortierellomycota, Ascomycota, and Basidiomycota, which were distributed in the second quadrant.

The results showed that the composition of soil bacterial and fungal communities was closely related to soil nutrient properties, such as soil $\mathrm{pH}, \mathrm{AN}, \mathrm{AP}$, and $\mathrm{AK}$, suggesting that the effect of biochar on soil community structure might be indirectly driven by the change in soil properties.

\section{Materials and Methods}

\subsection{Test Site}

The experiment was performed at the $26^{\circ} 10^{\prime} \mathrm{N}, 119^{\circ} 23^{\prime}$ E pot plant test base at Heilongjiang Bayi Agricultural University. The environmental parameters included an annual sunshine time of $2726 \mathrm{~h}$, a frost-free period of $166 \mathrm{~d}$, an annual average temperature of $4.2^{\circ} \mathrm{C}$, an annual precipitation of $427 \mathrm{~mm}$, and an annual evaporation of $1635 \mathrm{~mm}$.

\subsection{Test Materials}

The test soil type was Northeast Meadow albic soil that was acquired from 850 Farm Science and Technology Park, Hulin City, Heilongjiang Province, China. The background values of soil basic nutrients ( $0-20 \mathrm{~cm}$ plow layer) included a soil organic matter content of $34.80 \mathrm{~g} / \mathrm{kg}$, a soil total nitrogen content of $1.70 \mathrm{~g} / \mathrm{kg}$, a soil total phosphorus content of $0.88 \mathrm{~g} / \mathrm{kg}$, an alkali hydrolyzable nitrogen content of $162.00 \mathrm{mg} / \mathrm{kg}$, an available phosphorus content of $45.30 \mathrm{mg} / \mathrm{kg}$, an available potassium content of $97.00 \mathrm{mg} / \mathrm{kg}$, a pH value of 5.35 , and a CEC value of $10.16 \mathrm{cmol} / \mathrm{kg}$. Biochar was provided by Liaoning Jinhefu Co. Ltd., Liaoning, China. The total C content of corn stalk biochar was $50.60 \%$, the total $\mathrm{N}$ content was $1.4 \%$, the ash content was $15.34 \%$, and the $\mathrm{pH}$ value was 8.50 . The total $\mathrm{C}$ content, total $\mathrm{N}$ content, ash content, and $\mathrm{pH}$ value of rice straw biochar were $51.41 \%$, $1.45 \%, 23.89 \%$, and 7.87 , respectively. The rice variety was Kenjing 5 and was provided by the Rice Center of Heilongjiang Bayi Agricultural University.

\subsection{Experimental Design}

The pot experiment was conducted using a pot with a diameter of $30 \mathrm{~cm}$ and a height of $28 \mathrm{~cm}$. Rice straw and corn straw biochar were selected, and the treatments included SBCK (conventional control treatment with no biochar), SD (rice straw biochar $20 \mathrm{t} / \mathrm{ha}$ ), and SY (corn straw biochar $20 \mathrm{t} / \mathrm{ha}$ ) with a completely random design. Each treatment was set for 3 replicates, and each replicate comprised 20 pots. The weight of albic soil of each pot was $10 \mathrm{~kg}$. The application dosages were $131.4 \mathrm{~kg} \mathrm{~N} /$ ha with urea and diammonium phosphate, $69.0 \mathrm{~kg} \mathrm{P}_{2} \mathrm{O}_{5} /$ ha with diammonium phosphate, and $78.0 \mathrm{~kg}_{2} \mathrm{O} /$ ha with potassium sulfate.

Urea was applied five times in the form of basal fertilizer, tillering fertilizer, regulating fertilizer, panicle fertilizer, and grain fertilizer at compositions of $30 \%, 30 \%, 10 \%, 20 \%$, and $10 \%$, respectively. Phosphate fertilizer was used for all base fertilizer applications. Potassium fertilizer was applied twice as basal fertilizer and panicle fertilizer at compositions of $60 \%$ and $40 \%$, respectively. Biochar and albic soils were thoroughly mixed. Three holes of rice were planted in each pot, and three seedlings were planted in each hole. The rest of the experiments were performed according to the conventional management measures of rice, weeds, insects, and diseases, which were controlled by either chemical or manual methods to avoid yield loss.

\subsection{Sample Collection}

Rice rhizosphere soil with a depth of $0-20 \mathrm{~cm}$ was collected at the rice maturity stage by a stainless steel soil drill with a diameter of $2 \mathrm{~cm}$, and 10 points were randomly selected from each treatment. After removing the roots, weeds, soil animals, and other impurities, they were mixed and used as a repeated soil sample for the same treatment. The soil 
sample was put into aseptic sealed bag and temporarily stored in a low-temperature ice box and was taken back to the laboratory. The soil sample was divided into two parts after being screened by $2 \mathrm{~mm}$. Part of the soil samples was frozen at $-40{ }^{\circ} \mathrm{C}$ for analysis of microbial bacteria (16S rRNA) and fungal (18S rRNA) communities, the other part of the soil was air-dried for the analysis of soil chemical properties.

\subsection{Test Methods}

Soil samples (0.5 g) were weighed, and DNA was extracted using the Mobo Power Soil DNA Isolation Kit. The purity, concentration, and integrity of the DNA were detected by agarose gel electrophoresis and spectrophotometry. The V3 + V4 region of bacterial 16SRRNA was amplified using the following primers: 338F: 5'-ACTCCTACGGGAGCAGCA3' and 806R: 5'-GGACTACHVGGGTWTCTAAT-3'. The ITS1 region of the fungus was amplified using the following primers: 5'-CTTGGTCATTTAGAGGAAGTAA-3' and 5' GCTGCGTTCTTCATCGATGC-3'. The PCR amplification reaction volume was $50 \mu \mathrm{L}$. The reaction procedure included pre-denaturation at $95^{\circ} \mathrm{C}$ for $5 \mathrm{~min}, 35$ cycles of $95{ }^{\circ} \mathrm{C}$ for $30 \mathrm{~s}, 50{ }^{\circ} \mathrm{C}$ for $30 \mathrm{~s}$, and $72{ }^{\circ} \mathrm{C}$ for $40 \mathrm{~s}$, and then $72{ }^{\circ} \mathrm{C}$ for $7 \mathrm{~min}$. After amplification, the original library of the samples was established and sequenced using the Illumina HiSeq 2500 platform (Illumina Corporation, San Diego, CA, USA) with a $2 \times 250$ bp doubleended sequencing strategy. The original data were stitched (Flash, version 1.2.11), and the stitched sequences were filtered according to quality (Trimmomatic, version 0.33 ). The UCHIME (version 8.1) was removed to obtain the tag sequence with high quality. When the sample sequencing depth index value was greater than $99 \%$, the sequencing data were considered to be reasonable. The extraction and sequencing of soil microbial total DNA were performed by Beijing Biamark Biotechnology Co. Ltd., Beijing, China $[48,68]$.

Soil $\mathrm{pH}$ was measured in 1:2.5 ratio soil solutions (with de-ionized water) with a $\mathrm{pH}$ meter. The organic matter content was measured using the high temperature-volume method, with heating and oxidation by potassium dichromate. For total nitrogen, $\mathrm{H}_{2} \mathrm{SO}_{4}$ was used as an accelerator for digestion, and then the Kjeldahl analytic method was used. The soil alkali-hydrolyzable nitrogen was measured with the alkaline hydrolysis diffusion method. Available phosphorus was extracted with sodium bicarbonate and determined with ultraviolet spectrophotometry (TU-1810, Beijing Pgeneral Instrument Co. Ltd., Beijing, China). Total phosphorus was measured using the alkali fusion-molybdenum antimony anti-spectrophotometric method. Soil total potassium (TK) and available potassium (AK) were quantified using inductively coupled plasma-atomic emission spectrometry (ICPS7500, Shimadzu, Japan). All the above chemical indexes were measured according to Soil Agrochemical Analysis, which was published by China Agriculture Press [69].

\subsection{Data Processing and Analysis}

OTUs exhibiting a similarity of $97 \%$ were randomly selected to generate dilution curves, and the richness indices for Chao and Ace, Simpson, and Shannon were calculated using Mothur software (version 1.31.2). The OTU was annotated based on the RDP and Unite taxonomic databases, and Excel and SPSS were used for data processing. Excel and $\mathrm{R}$ language tools were used to draw histograms and Veen plots for the statistical results of species composition and relative abundance of the samples.

\section{Conclusions}

The results of this study revealed that the biochar increased the soil nutrient content of albic soil, and biochar addition increased soil bacteria and fungi abundance and altered community structure. The bacteria ACE indexes of SD and SY were increased by $3.10 \%$ and $2.06 \%$, respectively, and the fungi ACE and Chao indices of SD were increased by $7.86 \%$ and $14.16 \%$, respectively, compared to that of SBCK. Biochar increased the number of unique OTUs of bacteria and fungi in the soil. The relationship between soil bacteria and fungi in the biochar treatments was stronger than SBCK. In addition, the changes in the soil bacteria and fungi community compositions were closely related to soil nutrient 
characteristics, such as $\mathrm{pH}, \mathrm{OC}, \mathrm{AN}, \mathrm{AP}$, and $\mathrm{AK}$, and these characteristics were correlated with biochar addition, which suggested that the impacts of biochar on the soil bacteria and fungi community were indirectly driven by alternation of soil nutrient characteristics. The addition of two types of biochar altered the soil microbial community structure, and the effect of rice straw biochar treatment was more pronounced. These results aimed to provide a reference and basic understanding for albic soil improvement by biochar, with good application prospects.

Author Contributions: This work was carried out in collaboration between all authors. Authors D.Y. and H.L. performed the experimental investigation. Authors X.G., H.W., Y.L. (Yandong Lv), G.D. and Z.W. performed the data curation and the analysis and wrote the first draft of the manuscript. Corresponding author L.J. designed the study, performed the supervision, the writing-review and editing, and funding acquisition. Another corresponding author Y.L. (Yu Lan) performed the writing - review and the editing, and the project administration. All authors have read and agreed to the published version of the manuscript.

Funding: This work was funded by the National Key R\&D Program of China (2017YFD0200803), the National Natural Science Foundation of China (31901479), the Postdoctoral Foundation of Heilongjiang Province (LBH-Q20160), the Heilongjiang Province Agricultural Reclamation Bureau Project (HKKYZD190206). Moreover, the Heilongjiang Bayi Agricultural University Support Program for San Heng San Zong (TDJH201802).

Data Availability Statement: All data, models, and code generated or used during the study appear in the submitted article.

Acknowledgments: The all individuals appreciate the partial support of Shenyang Agricultural University.

Conflicts of Interest: The authors declare no conflict of interest.

Sample Availability: Samples of the soil from the test area are available from the authors.

\section{References}

1. Wang, X.H. The characteristic and influence factors of extinction depth of shallow groundwater on the high-latitude region: A case study on the Sanjiang Plain, northeast China. Environ. Sci. Pollut. Res. 2018, 25, 6695-6706. [CrossRef]

2. Xiu, L.; Zhang, W.; Sun, Y.; Wu, D.; Meng, J.; Chen, W. Effects of biochar and straw returning on the key cultivation limitations of Albic soil and soybean growth over 2 years. Catena 2019, 173, 481-493. [CrossRef]

3. Denef, K.; Roobroeck, D.; Manimel Wadu, M.C.W.; Lootens, P.; Boeckx, P. Microbial community composition and rhizodepositcarbon assimilation in differently managed temperate grassland soils. Soil Biol. Biochem. 2009, 41, 144-153. [CrossRef]

4. Brockett, B.F.; Prescott, C.E.; Grayston, S.J. Soil moisture is the major factor influencing microbial community structure and enzyme activities across seven biogeoclimatic zones in western Canada. Soil Biol. Biochem. 2012, 44, 9-20. [CrossRef]

5. Hewedy, O.A.; Abdel Lateif, K.S.; Seleiman, M.F.; Shami, A.; Albarakaty, F.M.; El-Meihy, M.R. Phylogenetic diversity of trichoderma strains and their antagonistic potential against soil-borne pathogens under stress conditions. Biology 2020, 9, 189. [CrossRef]

6. Degens, B.P.; Schipper, L.A.; Sparling, G.P.; Vojvodic-Vukovic, M. Decreases in organic $\mathrm{C}$ reserves in soils can reduce the catabolic diversity of soil microbial communities. Soil Biol. Biochem. 2000, 32, 189-196. [CrossRef]

7. Ojuederie, O.B.; Olanrewaju, O.S.; Babalola, O.O. Plant growth promoting rhizobacterial mitigation of drought stress in crop plants: Implications for sustainable agriculture. Agronomy 2019, 9, 712. [CrossRef]

8. Sarfraz, R.; Hussain, A.; Sabir, A.; Fekih, I.B.; Ditta, A.; Xing, S.H. Role of biochar and plant growth promoting rhizobacteria to enhance soil carbon sequestration-A review. Environ. Monit. Assess. 2019, 191, 251. [CrossRef]

9. Danish, S.; Zafar-Ul-Hye, M.; Mohsin, F.; Hussain, M. ACC-deaminase producing plant growth promoting rhizobacteria and biochar mitigate adverse effects of drought stress on maize growth. PLoS ONE 2020, 15, e0230615. [CrossRef] [PubMed]

10. Zafar-Ul-Hye, M.; Danish, S.; Abbas, M.; Ahmad, M.; Munir, T.M. ACC deaminase producing PGPR Bacillus amyloliquefaciens and Agrobacterium fabrum along with biochar improve wheat productivity under drought stress. Agronomy 2019, 9, 343. [CrossRef]

11. Jiao, Y.; Li, D.; Wang, M.; Gong, T.C.; Sun, M.Y.; Yang, T.X. A scientometric review of biochar preparation research from 2006 to 2019. Biochar 2021, 3, 283-298. [CrossRef]

12. Pranagal, J.; Oleszczuk, P.; Tomaszewska-Krojańska, D.; Kraska, P.; Różyło, K. Effect of biochar application on the physical properties of Haplic Podzol. Soil. Tillage Res. 2017, 174, 92-103. [CrossRef]

13. Rizwan, M.S.; Imtiaz, M.; Zhu, J.; Yousaf, B.; Hu, H. Immobilization of $\mathrm{pb}$ and cu by organic and inorganic amendments in contaminated soil. Geoderma 2021, 385, 114803. [CrossRef] 
14. Alkharabsheh, H.M.; Seleiman, M.F.; Battaglia, M.L.; Shami, A.; Jalal, R.S.; Alhammad, B.A.; Almutairi, K.F.; Al-Saif, A.M. Biochar and its broad impacts in soil quality and fertility, nutrient leaching and crop productivity: A review. Agronomy 2021, 11, 993. [CrossRef]

15. Seleiman, M.F.; Alotaibi, M.A.; Alhammad, B.A.; Alharbi, B.M.; Refay, Y.; Badawy, S.A. Effects of ZnO nanoparticles and biochar of rice straw and cow manure on characteristics of contaminated soil and sunflower productivity, oil quality, and heavy metals uptake. Agronomy 2020, 10, 790. [CrossRef]

16. Seleiman, M.F.; Refay, Y.; Al-Suhaibani, N.; Al-Ashkar, I.; El-Hendawy, S.; Hafez, E.M. Integrative effects of rice-straw biochar and silicon on oil and seed quality, yield and physiological traits of Helianthus annuus L. grown under water deficit stress. Agronomy 2019, 9, 637. [CrossRef]

17. Ullah, N.; Ditta, A.; Imtiaz, M.; Li, X.M.; Jan, A.U.; Mehmood, S.; Rizwan, M.S.; Rizwan, M. Appraisal for organic amendments and plant growth-promoting rhizobacteria to enhance crop productivity under drought stress: A review. J. Agron. Crop. Sci. 2021. [CrossRef]

18. Li, M.Y.; Sun, W.J.; Wang, Y.J.; Sun, D.A.; Tan, Y.Z. Air permeability of biochar-amended clay cover. Arab. J. Geosci. 2021, 14, 732. [CrossRef]

19. Dai, Z.; Xiong, X.; Zhu, H.; Xu, H.; Xu, J. Association of biochar properties with changes in soil bacterial, fungal and fauna communities and nutrient cycling processes. Biochar 2021, 3, 239-254. [CrossRef]

20. Murtaza, G.; Ditta, A.; Ullah, N.; Usman, M.; Ahmed, Z. Biochar for the management of nutrient impoverished and metal contaminated soils: Preparation, applications, and prospects. J. Soil. Sci. Plant. Nut. 2021, 1-23. [CrossRef]

21. Maienza, A.; Baronti, S.; Cincinelli, A.; Martellini, T.; Grisolia, A.; Miglietta, F.; Renella, G.; Stazi, S.R.; Vaccari, F.P.; Genesio, L. Biochar improves the fertility of a Mediterranean vineyard without toxic impact on the microbial community. Agron. Sustain. Dev. 2017, 37, 47. [CrossRef]

22. Chen, J.H.; Sun, X.; Zheng, J.F.; Liu, X.; Bian, R.; Li, L.; Cheng, K.; Zheng, J.; Pan, G. Biochar amendment changes temperature sensitivity of soil respiration and composition of microbial communities 3 years after incorporation in an organic carbon-poor dry cropland soil. Biol. Fert. Soils 2018, 54, 175-188. [CrossRef]

23. Zhao, B.; Niebuhr, A.J.; Lv, Y.; Douangdalangsy, K. Effects of soybean stover-derived biochar on microbial community and structure in loess soil. Nat. Environ. Pollut. Technol. 2020, 19, 703-710. [CrossRef]

24. Zhang, Y.; Zhao, C.; Chen, G.; Zhou, J.L.; Chen, Z.; Li, Z.X.; Zhu, J.W.; Feng, T.; Chen, Y.Q. Response of soil microbial communities to additions of straw biochar, iron oxide, and iron oxide-modified straw biochar in an arsenic-contaminated soil. Environ. Sci. Pollut. Res. 2020, 27, 23761-23768. [CrossRef]

25. Roy, R.; Núez-Delgado, A.; Sultana, S.; Wang, J.; Mmunirf, A.; Battaglia, M.; Sarker, T.; Seleiman, M.F.; Barmon, M.; Zhang, R.Q. Additions of optimum water, spent mushroom compost and wood biochar to improve the growth performance of althaea rosea in drought-prone coal-mined spoils. J. Environ. Manag. 2021, 295, 113076. [CrossRef]

26. Gul, S.; Whalen, J.K. Biochemical cycling of nitrogen and phosphorus in biochar amended soils. Soil Biol. Biochem. 2016, 103, 1-15. [CrossRef]

27. Luo, X.X.; Liu, G.C.; Xia, Y.; Chen, L.; Jiang, Z.X.; Zheng, H.; Wang, Z.Y. Use of biocharcompost to improve properties and productivity of the degraded coastal soil in the Yellow River Delta, China. J. Soils Sediments 2017, 17, 780-789. [CrossRef]

28. Sun, H.J.; Lu, H.Y.; Chu, L.; Shao, H.B.; Shi, W.M. Biochar applied with appropriate rates can reduce N leaching, keep N retention and not increase NH3 volatilization in a coastal saline soil. Sci. Total. Environ. 2017, 575, 820-825. [CrossRef]

29. Agegnehu, G.; Srivastava, A.K.; Bird, M.I. The role of biochar and biochar-compost in improving soil quality and crop performance: A review. Appl. Soil Ecol. 2017, 119, 156-170. [CrossRef]

30. Ding, Y.; Liu, Y.; Liu, S.; Li, Z.; Tan, X.; Huang, X.; Zeng, G.; Zhou, L.; Zheng, B. Biochar to improve soil fertility. A review. Agron. Sustain. Dev. 2016, 36, 35-52. [CrossRef]

31. El-Naggar, A.; Lee, S.S.; Rinklebe, J.; Farooq, M.; Song, H.; Sarmah, A.K.; Ok, Y.S. Biochar application to low fertility soils: A review of current status, and future prospects. Geoderma 2019, 337, 536-554. [CrossRef]

32. Cui, Q.; Xia, J.; Yang, H.; Liu, J.; Shao, P. Biochar and effective microorganisms promote Sesbania cannabina growth and soil quality in the coastal saline-alkali soil of the Yellow River Delta, China. Sci. Total. Environ. 2021, 756, 143801. [CrossRef]

33. Li, S.L.; Wang, S.; Fan, M.C.; Wu, Y.; Shangguan, Z.P. Interactions between biochar and nitrogen impact soil carbon mineralization and the microbial community. Soil. Tillage Res. 2020, 196, 104437. [CrossRef]

34. Lucheta, A.R.; Cannavan, F.D.S.; Roesch, L.; Tsai, S.M.; Kuramae, E.E. Fungal community assembly in the amazonian dark Earth. Microb. Ecol. 2016, 71, 962-973. [CrossRef]

35. Hu, L.; Cao, L.X.; Zhang, R.D. Bacterial and fungal taxon changes in soil microbial community composition induced by short-term biochar amendment in red oxidized loam soil. World J. Microb. Biotechnol. 2014, 30, 1085-1092. [CrossRef]

36. Liu, G.L. Effects of Transgenic Soybeans on the Rhizospheric Soil Microbial Communities and Their Diversity Indices Measurement. Ph.D. Thesis, Nanjing University, Nanjing, China, 2012. (In Chinese).

37. Muhammad, N.; Dai, Z.; Xiao, K.; Meng, J.; Brookes, P.C.; Liu, X.; Wang, H.; Wu, J.; Xu, J. Changes in microbial community structure due to biochars generated from different feedstocks and their relationships with soil chemical properties. Geoderma 2014, 226-227, 270-278. [CrossRef]

38. Yao, Q.; Liu, J.; Yu, Z.; Li, Y.; Jin, J.; Liu, X.; Wang, G. Changes of bacterial community compositions after three years of biochar application in a black soil of northeast China. Appl. Soil Ecol. 2017, 113, 11-21. [CrossRef] 
39. Ji, F.Y.; Ming, H.X.; Li, H.B.; Zan, S.J.; Wang, J.N.; Su, J.; Guo, L.M.; Chang, Y.K.; Shi, Y.; Guan, C.J.; et al. Diversity of CO 2 fixation gene in the surface waters of northern South China Sea in the Calvin cycle. Acta Sci. Circumst. 2016, 36, 4037-4043. (In Chinese)

40. Liu, Q.; Wei, X.M.; Wu, X.H.; Yuan, H.C.; Wang, J.R.; Li, Y.Y.; Ge, T.D.; Wu, J.S. Characteristic of abundances and diversity of carbon dioxide fixation microbes in paddy soils. Environ. Sci. 2017, 38, 760-768. (In Chinese)

41. Fierer, N.; Bradford, M.A.; Jackson, R.B. Toward an ecological classification of soil bacteria. Ecology 2007, 88, 1354. [CrossRef] [PubMed]

42. Cottrell, M.T.; Kirchman, D.L. Natural assemblages of marine proteobacteria and members of the Cytophaga-Flavobacter cluster consuming low- and high-molecularweight dissolved organic matter. Appl. Environ. Microbiol. 2000, 66, 1692-1697. [CrossRef] [PubMed]

43. Jones, R.T.; Robeson, M.S.; Lauber, C.L.; Hamady, M.; Knight, R.; Fierer, N. A comprehensive survey of soil acidobacterial diversity using pyrosequencing and clone library analyses. ISME J. 2009, 3, 442-453. [CrossRef]

44. Keiblinger, K.M.; Hall, E.K.; Wanek, W.; Szukics, U.; Hämmerle, I.; Ellersdorfer, G.; Böck, S.; Strauss, J.; Sterflinger, K.; Richter, A.; et al. The effect of resource quantity and resource stoichiometry on microbial carbon-use-efficiency. FEMS Microbiol. Ecol. 2010, 73, 430-440. [CrossRef] [PubMed]

45. Ramirez, K.S.; Craine, J.M.; Fierer, N. Consistent effects of nitrogen amendments on soil microbial communities and processes across biomes. Glob. Chang. Biol. 2012, 18, 1918-1927. [CrossRef]

46. Hug, L.A.; Castelle, C.J.; Wrighton, K.C.; Thomas, B.C.; Sharon, I.; Frischkorn, K.R.; Williams, K.H.; Tringe, S.G.; Banfield, J.F. Community genomic analyses constrain the distribution of metabolic traits across the Chloroflexi phylum and indicate roles in sediment carbon cycling. Microbiome 2013, 1, 22. [CrossRef]

47. Ali, N.; Khan, S.; Li, Y.; Zheng, N.; Yao, H. Influence of biochars on the accessibility of organochlorine pesticides and microbial community in contaminated soils. Sci. Total. Environ. 2019, 647, 551-560. [CrossRef]

48. Yao, Q.; Liu, J.; Yu, Z.J.; Li, Y.; Jin, J.; Liu, X.; Wang, G. Three years of biochar amendment alters soil physiochemical properties and fungal community composition in a black soil of northeast China. Soil Biol. Biochem. 2017, 110, 56-67. [CrossRef]

49. Liu, H.; Pan, F.J.; Han, X.Z.; Song, F.B.; Zhang, Z.M.; Yan, J.; Xu, Y.L. A comprehensive analysis of the response of the fungal community structure to long-term continuous cropping in three typical upland crops. J. Integr. Agric. 2020, 19, 866-880. [CrossRef]

50. Dai, Z.M.; Enders, A.; Rodrigues, J.; Hanley, K.; Brookes, P.; Xu, J.M.; Lehmann, J. Soil fungal taxonomic and functional community composition as affected by biochar properties. Soil Biol. Biochem. 2018, 126, 159-167. [CrossRef]

51. Wang, Y. Effects of Biochar Combined with Plant Growth Promoting Rhizobacteria (PGPR) on Crop Growth and Soil Physical, Chemical and Biological Properties; Shandong Agricultural University: Qingdao, China, 2019.

52. Ullah, N.; Ditta, A.; Khalid, A.; Mehmood, S.; Rizwan, M.S.; Ashraf, M.; Mubeen, F.; Imtiaz, M.; Iqbal, M.M. Integrated effect of algal biochar and plant growth promoting rhizobacteria on physiology and growth of maize under water deficit irrigations. J. Soil Sci. Plant Nutr. 2020, 20, 346-356. [CrossRef]

53. Chen, S.; Rotaru, A.E.; Shrestha, P.M.; Malvankar, N.S.; Liu, F.; Fan, W.; Nevin, K.P.; Lovley, D.R. Promoting interspecies electron transfer with biochar. Sci. Rep. 2014, 4, 5019. [CrossRef]

54. Hale, L.; Luth, M.; Kenney, R.; Crowley, D. Evaluation of pinewood biochar as a carrier of bacterial strain Enterobacter cloacae UW5 for soil inoculation. Appl. Soil Ecol. 2014, 84, 192-199. [CrossRef]

55. Liu, S.D.; Han, G.Y.; Zhu, X.P.; Wu, X.N. Effects of cotton stalk carbon regulation on fungal community structure and function in alkaline Cadmium contaminated rice rhizosphere soil. Environ. Sci. 2020, 41, 3846-3854. (In Chinese)

56. Li, S.; Liang, C.; Shangguan, Z.P. Effects of apple branch biochar on soil C mineralization and nutrient cycling under two levels of N. Sci. Total. Environ. 2017, 607-608, 109-111. [CrossRef]

57. Liu, J.; Sui, Y.; Yu, Z.; Shi, Y.; Chu, H.; Jin, J. Soil carbon content drives the biogeographical distribution of fungal communities in the black soil zone of Northeast China. Soil Biol. Biochem. 2015, 83, 29-39. [CrossRef]

58. Liu, J.; Zhang, X.; Kennedy, J.F.; Jiang, M.; Wu, X. Chitosan induces resistance to tuber rot in stored potato caused by alternaria tenuissima. Int. J. Biol. Macromol. 2019, 140, 13204. [CrossRef] [PubMed]

59. Lehmann, J.; Rillig, M.C.; Thies, J.; Masiello, C.A.; Hockaday, W.C.; Crowley, D. Biochar effects on soil biota-A review. Soil Biol. Biochem. 2011, 43, 1812-1836. [CrossRef]

60. Ma, L.N. Study on Soil Microbial Response Characteristics of Soda Saline-Sodic Soil Improved by Rice Cultivation in Northeast China; University of Chinese Academy of Sciences: Haerbin, China, 2020.

61. Chen, H.; Boutros, P.C. VennDiagram: A package for the generation of highly-customizable Venn and Euler diagrams in R. BMC Bioinform. 2011, 12, 35. [CrossRef] [PubMed]

62. Cao, H.; Li, Y.G.; Zhou, C.R.; Ning, L.F.; Yang, H.Q. Effects of carbonized apple branches on soil bacterial and fungal diversity in apple root zone. Sci. Agric. Sin. 2016, 49, 3413-3424.

63. Ding, Y.L.; Liu, J.; Wang, Y.Y. Effects of biochar on microbial ecology in agriculture soil: A review. Chin. J. Appl. Ecol. 2013, 24, 3311-3317. (In Chinese)

64. Guo, Y.; Sun, B.H.; Wang, Y.; Wei, J.; Gao, M.X.; Zhang, S.L.; Yang, X.Y. PLFA fingerprint characteristics of an anthropogenic loess soil under long-term different fertilizations. Sci. Agric. Sin. 2017, 50, 94-103. (In Chinese)

65. Yue, L.Y.; Zheng, J.Q.; Han, S.J.; Yang, J.H.; Geng, S.C.; Chen, Z.J.; Zhang, X.; Gu, Y. Soil chemical properties and microbial community structure at different succession stages of temperate forest in Changbai Mountains. Chin. J. Ecol. 2015, 34, 2590-2597. (In Chinese) 
66. Li, C.Y.; Wang, Y.; Brookes, P.; Dang, T.H.; Wang, W.Z. Effect of soil pH on soil microbial carbon phosphorus ratio. Sci. Agric. Sin. 2013, 46, 2709-2716. (In Chinese)

67. Xu, Y.C.; Shen, Q.R.; Ran, W. Effects of zero-tillage and application of manure on soil microbial biomass C, N and P after sixteen years of cropping. Acta Pedol. Sin. 2002, 39, 83-90. (In Chinese)

68. Yang, L.; Jiang, M.; Zhu, W.; Han, L.; Qin, L. Soil bacterial communities with an indicative function response to nutrients in wetlands of Northeastern China that have undergone natural restoration. Ecol. Indic. 2019, 101, 562-571. [CrossRef]

69. Bao, S.D. Soil and Agricultural Chemistry Analysis, 3rd ed.; Chinese Agriculture Press: Beijing, China, 2000. (In Chinese) 